NBER WORKING PAPER SERIES

THE ELECTORAL CONSEQUENCES OF LARGE FISCAL ADJUSTMENTS

\author{
Alberto F. Alesina \\ Dorian Carloni \\ Giampaolo Lecce \\ Working Paper 17655 \\ http://www.nber.org/papers/w17655
}

\author{
NATIONAL BUREAU OF ECONOMIC RESEARCH \\ 1050 Massachusetts Avenue \\ Cambridge, MA 02138
}

December 2011

The views expressed herein are those of the authors and do not necessarily reflect the views of the National Bureau of Economic Research.

NBER working papers are circulated for discussion and comment purposes. They have not been peerreviewed or been subject to the review by the NBER Board of Directors that accompanies official NBER publications.

(C) 2011 by Alberto F. Alesina, Dorian Carloni, and Giampaolo Lecce. All rights reserved. Short sections of text, not to exceed two paragraphs, may be quoted without explicit permission provided that full credit, including $\odot$ notice, is given to the source. 
The Electoral Consequences of Large Fiscal Adjustments

Alberto F. Alesina, Dorian Carloni, and Giampaolo Lecce

NBER Working Paper No. 17655

December 2011

JEL No. H2,H3,H5

\begin{abstract}
$\underline{\text { ABSTRACT }}$
The conventional wisdom regarding the political consequences of large reductions of budget deficits is that they are very costly for the governments which implement them: they are punished by voters at the following elections. In the present paper, instead, we find no evidence that governments which quickly reduce budget deficits are systematically voted out of office in a sample of 19 OECD countries from 1975 to 2008. We also take into consideration issues of reverse causality, namely the possibility that only "strong and popular" governments can implement fiscal adjustments and thus they are not voted out of office "despite" having reduced the deficits. In the end we conclude that many governments can reduce deficits avoiding an electoral defeat.
\end{abstract}

\author{
Alberto F. Alesina \\ Giampaolo Lecce \\ Department of Economics \\ Bocconi University \\ Harvard University \\ glecce@phd.unibocconi.it \\ Littauer Center 210 \\ Cambridge, MA 02138 \\ and IGIER \\ and also NBER \\ aalesina@harvard.edu \\ Dorian Carloni \\ University of California, Berkeley \\ dcarloni@econ.berkeley.edu
}




\title{
The Electoral Consequences of Large Fiscal Adjustments
}

\author{
Alberto Alesina \\ Dorian Carloni \\ Giampaolo Lecce \\ Harvard and IGIER \\ UC Berkeley \\ Bocconi University
}

Preliminary Draft: November 2011

\begin{abstract}
The conventional wisdom regarding the political consequences of large reductions of budget deficits is that they are very costly for the governments which implement them: they are punished by voters at the following elections. In the present paper, instead, we find no evidence that governments which quickly reduce budget deficits are systematically voted out of office in a sample of 19 OECD countries from 1975 to 2008 . We also take into consideration issues of reverse causality, namely the possibility that only "strong and popular" governments can implement fiscal adjustments and thus they are not voted out of office "despite" having reduced the deficits. In the end we conclude that many governments can reduce deficits decisively avoiding an electoral defeat.
\end{abstract}

\section{Introduction}

The conventional wisdom regarding the political consequences of large reductions of budget deficits (which we label "fiscal adjustments") is that they are the kiss of death for the governments which implement them: they are punished by voters at the following elections. In certain countries spending cuts are very unpopular, in others tax increases are politically more costly but everywhere, the story goes, fiscal rigor is always unpopular.

The empirical evidence on this point is much less clear cut than the conviction with which this conventional wisdom is held. In the present paper, in fact, we find no evidence that governments which reduce budget deficits even decisively are systematically voted out of office. We also take into consideration as carefully as possible issues of reverse causality, namely the possibility that only "strong and popular" governments can implement fiscal adjustments and thus they are not voted out of office "despite" having reduced the deficits. Even taking this possibility into account we still find no evidence that fiscal adjustments, even decisive ones, systematically, on average, imply electoral defeats.

In the present paper our focus is especially in large fiscal adjustments, which are currently at the center of attention in many OECD countries. As a motivation we begin by examining the evidence on the ten largest multi-year fiscal adjustments in the last 30 years in OECD countries. We find no evidence that the turnover of governments in those periods was significantly higher than the average of the entire sample. In fact it was lower. ${ }^{1}$ We then explore more systematically all cases of large adjustments (defined as a reduction of at least 1.5 per cent of GDP of cyclically adjusted deficits). Once

\footnotetext{
${ }^{1}$ Obviously there is some arbitrariness in how to define 10 "largest" adjustments, but the result on their political consequences hold regardless of which (reasonable) definition is used.
} 
again we find no evidence of a negative effect on election prospects. Contrary to the conventional wisdom, we find some evidence that fiscally loose government tend to lose election more often than average, a result which is consistent with Brander and Drazen (2008). Next, we present a battery of regressions which show that indeed these results are quite robust and the data do not exhibit any correlation between deficit reduction and electoral losses.

But what about reverse causality? Perhaps weak governments, knowing their vulnerability, do not implement adjustments, but then, precisely because they are weak, they loose at polls, and the reverse holds for strong governments. This would explain the lack of correlation between fiscal adjustments and reelection. Unfortunately measuring the "strength" of a government is not easy; often such strength or weakness depends on personalities involved, leadership style etc. which are impossible for the econometrician to observe and measure. For instance, in principle a coalition government may be weaker and more unstable than a single party government, but certain coalitions may be especially cohesive and certain single party government may hide strong division within the same party. The margin of the majority of the government in the legislature may be an other indicator, but that too could be imperfect, due for instance, to divisions within the government coalition even though the latter may have a large majority of seats. We find no evidence of a different behavior in terms of fiscal adjustments of coalition versus single party governments. At the very least we can conclude that many governments can tackle decisively budget deficits without electoral losses. Perhaps not all, but a good portion can. ${ }^{2}$

If it is the case that fiscal adjustments do not lead systematically to electoral defeats why do they often seem so politically difficult? We can think of two explanations. The first one is simply risk aversion. Incumbent governments may be afraid of "rocking the boat" and follow a cautious course of actions and postpone fiscal reforms. The second and perhaps more plausible one is that the political game played around a fiscal adjustment goes above and beyond a one man one vote elections. Alesina and Drazen (1991) present a model in which organized groups with a strong influence on the polity manage to postpone reforms, even when the latter are necessary and unavoidable, to try to switch the costs on their opponents. The resulting wars of attrition delays fiscal adjustments. Strikes, contributions from various lobbies, press campaigns are all means which can enforce (or block) policies above and beyond voting at the polls. For example imagine a public sector union that goes on strike to block reduction in government spending on the public wage bill. They may create disruptions and may have consequences which may be too costly to bear for a government. Not only, but public sector unions may have connections with parts of the incumbent coalition and block fiscal adjustments. Similar considerations may lead to postponements of pension reforms. In many countries pensioners developed a strong political support even within workers' unions. The latter would then water down the adjustment to placate this particular lobby even though the "median voter" might have been favorable to the tighter fiscal policy. To put it more broadly, voting in elections is not the only way in which various lobbies and pressure groups can influence the political process. Alesina, Ardagna and Trebbi (2006) present a battery of tests on electoral reform in large sample of countries which are consistent with the empirical implications of the war of attrition model.

The paper closest to the present one in spirit is Alesina, Perotti and Tavares (1998). These authors, using data up to the mid nineties, found inconclusive evidence on the effects of fiscal adjustments on reelections in OECD economies. Buti et al. (2010) find that chances of reelection for the incumbent governments are, controlling for other factors,

\footnotetext{
${ }^{2}$ See Bonfiglioli and Gancia (2010) for a model based upon politicians' competence in which certain but not all governments implement fiscal reforms and those which do are reelected.
} 
not significantly affected by their record of pro-market reforms ${ }^{3}$. A related literature is the one on political budget cycles which asks the question of whether incumbent governments increase spending or cut taxes before elections in order to be rewarded at the polls, an argument which implies that budget deficits are popular and budget cuts are not. ${ }^{4}$ Persson and Tabellini (2000) suggested that only in certain types of electoral systems political budget cycles are present. However Brander and Drazen (2005) show in fact that while political budget cycles are common in new democracies (like in Central and Eastern Europe) they are not the norm in established one, where increases in deficits tend to reduce the electoral success for the incumbents.

The rest of the paper is organized as follows. In Section 2 we briefly describe our data. Section 3 presents some suggestive qualitative evidence on the largest multi year fiscal adjustments in the OECD countries in the last 30 years. Section 4 discusses more formally the correlations between deficit reduction policies and electoral results. Section 5 addresses the question of potential reverse causality. In Section 6 we look at some case studies to further illustrate the link between fiscal adjustment and re-election prospects. The last section concludes.

\section{Data}

Our data sources are standard. For economic variables we use OECD Economic Outlook Database no.84. For political-institutional variables we use the Database of Political Institutions (DPI) 2009. In particular we focus on the period 1975-2008. The countries are the members of the OECD which have been such for the entire period; the ones we analysed in our work are 19: Australia, Austria, Belgium, Canada, Denmark, Finland, France, Germany, Greece, Ireland, Italy, Japan, Netherlands, Norway, Portugal, Spain, Sweden, United Kingdom and United States.

The precise definition of all our variables is extensively described in Appendix, but for ease of exposition we also redefine them as we encounter them in the paper. Specifically, all the variables corrected for the cycle are calculated using the cyclical adjusted variables of OECD Economic Outlook Database, and variation of cyclical adjusted variables are calculated over the potential output of total economy. In particular we used OECD reviewed and revised estimation methods. In order to provide a single measure of potential output, the chosen measure is "one which represents the levels of real GDP, and associated rates of growth, which are sustainable over the medium term at a stable rate of inflation" (Giorno et al., 1995). Our results are virtually identical if instead by dividing by potential GDP we divide by actual GDP. Fortunately the qualitative nature of our results is unaffected by the definition used.

\section{The 10 Largest Fiscal Adjustments}

We begin with some suggestive evidence regarding the ten largest fiscal adjustments in our sample. In Table 1 we report in order of cumulative size, the ten largest ones identified as follows: the ten cases in which the cumulative cyclically adjusted deficit reductions obtained by summing consecutive years of deficit reductions is the largest.

\footnotetext{
${ }^{3}$ In Buti et al. (2008) the empirical evidence also suggests that well-functioning and developed financial markets positively affect the reelection probability of reformist governments. It seems to suggest that financial market reforms facilitate reforms in product and labour markets.

Buti and van den Noord (2004a) and (2004b) also found the empirical evidence of political business cycle in the early years of EMU. These results suggests that electoral manipulation of fiscal policy in EU countries has not been curbed by EMU's fiscal policy rules.

${ }^{4}$ See Rogoff and Sibert (1988), Persson and Tabellini (2000) and Drazen (2004).
} 
Obviously one could think of alternative definitions but our qualitative results do not change. For instance we obtained very similar findings using a classification of the largest multi year fiscal adjustments used by Alcidi and Gros (2010).

Many of the episodes listed in our Table 1 have been made "famous" by a lively literature which has investigated the economic characteristic and degree of success of these episodes. ${ }^{5}$ In addition to the size of the adjustments in terms of deficit reduction we also report measures of the composition of the adjustment arising from spending cuts and tax increases over GDP. We calculate this variable by dividing the share of spending cuts over the reductions of fiscally adjusted deficits (in shares of potential GDP). Note that the spending share can be greater than 100 if taxes were actually cut during the adjustment or can be negative if spending was increased. We focus on this variable since the evidence shows that spending based fiscal adjustments have been more long lasting and more successful in achieving fiscal balance with lower costs in terms of lost growth. ${ }^{6}$ With "termination" we imply that there was an election in the period of the adjustments and/or in the two years following the end of it. We include the two years after the end of the fiscal adjustment because the results of an election within two years after the end of the period of deficit reduction could be affected by the tight fiscal policy quite directly. Beyond two years too much time may have elapsed to attribute reelection (or defeat) mainly to the fiscal adjustment. In any event our results do not quantitatively change if we include all terminations following the last year of the fiscal adjustments, even beyond two years. The last column, labelled "change in ideology" indicates how many changes in the political orientation occur during the fiscal adjustment and in the two years which followed its end.

Table 1 shows that government changes occurred in 7 cases out of 19 terminations, thus they were about 37 percent of the total. But if we look at the five largest adjustments in cumulative size, the ratio decreases considerably, as changes in government occurred only in 1 case out of 10 . On the contrary, there were about 40 percent of government changes over the total number of terminations from 1975 to 2008 for the countries sampled in the table, indicating that periods of large fiscal adjustments were not associated with sistematically higher government turnover.

Secondly the table allows us to make some preliminary observations about the link between cabinet change and the composition of fiscal adjustments. Considering the percentage of the adjustment due to cut in expenditures, and comparing the five fiscal adjustments for which the value was highest with the remaining adjustments, we find that the cases in which the expenditure share of the adjustment was higher were associated with less frequent change in government. In the table below, if we pool together data for Ireland (1986-89), Canada (1993-97), Finland (1993-98), Belgium (1982-1987) an Sweden (1994-2000), we get that government change occurred only in 20 percent of cases. Instead, for the rest of the countries considered, government changed in 56 percent of cases. This first evidence seems to suggest that tax-based adjustments make it more difficult for incumbent governments to be reappointed when they implement large fiscal adjustments.

\footnotetext{
${ }^{5}$ See the original contribution by Giavazzi and Pagano (1990). The most recent paper in this line which also summarizes the previous literature is Alesina and Ardagna (2010).

${ }^{6} \mathrm{~A}$ long list of papers on fiscal adjustments has reached this conclusion. The latest in this series is Alesina and Ardagna (2010). This paper also includes a review of the previous literature. Using a different methodology IMF(2010) also shows that spending based adjustments are less costly than tax based ones.
} 


\section{Deficit Reductions and Elections}

\subsection{Simple Statistics}

We now turn to a more systematic analysis of deficit reduction policies in OECD countries. We define a year of "large fiscal adjustment" one in which the cyclically adjusted deficit over potential GDP ratio fell by more than 1.5 per cent of GDP while a year of "fiscal adjustment" is one in which the cyclically adjusted deficit over potential GDP ratio falls by any amount. Thus, large fiscal adjustments are a subset of all the adjustments. Fiscal expansions are defined identically to fiscal adjustments but with the opposite sign.

With the definition of a "large fiscal adjustment", and given that the deficit is cyclically adjusted, one tries to capture years in which fiscal policy was decisively contractionary with, most likely, active discretionary fiscal policies which were not business as usual or the result of the cycle. When we use the cyclically adjusted definition of primary deficit (COCHDEF), we find 294 years (over 646 total) of fiscal adjustments and 60 years of "large" fiscal adjustments in our sample. We have more years of large fiscal adjustments if we consider not potential but actual GDP at the denominators of the ratios, but our results on the electoral consequences are completely unchanged. ${ }^{7}$

In this section we examine the link between the timing of fiscal adjustments and the timing of changes in government. In order to measure "changes of government" we use two variables, one is all changes of a Prime Minister (ALLCH), the other one is change of the Prime Minister and in the party composition of the government (IDEOCH). ${ }^{8}$ The first variable may overestimate "change", since a new Prime Minister with the same party or coalition may simply be a routine personnel replacement in a stable and reelected government. The variable IDEOCH may underestimate political turnover because even without a change in the party composition of the government, a Prime Minister may be changed because he/she may have become unpopular possibly as a result of a fiscal tightening.

Another data complication relates to the timing of government change. The issue can be summarized as follows: if the government termination occurs in the first part of year $\mathrm{t}$, should we consider the fiscal variable at time $\mathrm{t}$ as before or after the termination? If for example we were associating a change in government in the first part of year $t$ with a reduction in deficit over GDP in year t, we could erroneously conclude that the change in government occured as a result of the fiscal adjustment, although the fiscal adjustment could have been largely implemented in the second half of year t, after the elections. Hence, we adopt the same rule used in Alesina, Perotti and Tavares (1998): every termination that occurs between July 1 of year $t$ and June 30 of year $t+1$ is considered to fall in calendar year $t$ and is thought as contemporaneous to the fiscal outcomes of year t. Terminations that occured in the first part of each year are instead considered as contemporaneous to the fiscal variables of the previous year.

In Figures 1 and 2 we plot the frequency of ALLCH and IDEOCH in the election year against cyclically adjusted deficit reductions of different sizes and fiscal expansions in the three years before the election, and we do not find evidence that fiscal adjustments are associated with more frequent changes in government or prime minister. Figure 1 investigates the frequency of change in government and/or prime minister (ALLCH). The left-hand set of bars in the figure indicates the frequency of change when the adjustment takes place one year before the election. The first two bars from the left show the average value of ALLCH when there is a fiscal adjustment and a fiscal expansion. There is a

\footnotetext{
${ }^{7}$ This explains why with this method of dividing by potential GDP we identify slightly fewer large adjustments than in Alesina and Ardagna (2010).

${ }^{8}$ Excluding from the count of ALLCH the cases in which term limits were binding, like the second term of an American President, leave our results unchanged.
} 
slightly higher propensity for a government turnover after a fiscal expansion, even though the difference is not statistically significant; the third and fourth bar show equivalent statistics but divide fiscal adjustments by size. They seem to show that large adjustments one year before the elections are associated with lower propensity to government changes. The same picture emerges when we consider adjustment two years before the elections.

In Figure 2 we consider only government changes, defined as changes in the political orientation of the government (IDEOCH). Figure 2 provides comparable results to Figure 1 , except for the fact that the dependent variable is now IDEOCH instead of ALLCH. This figure does not show that incumbent governments are systematically voted out of office when they implement deficit reductions. The results we get in Figure 2 are similar to those we got in Figure 1, as they show that fiscal expansions (i.e. increases in deficits) are on average associated with higher government change than fiscal adjustments.

Figure 3 sheds some light on the relationship between the composition of the adjustment and government turnover. We label large adjustments as expenditure based when spending cuts are greater than the median spending cut of all large fiscal adjustments. They are tax-based if the increase in tax revenues is greater than the median tax increase of all large fiscal adjustments. Consistently with the preliminary evidence provided in the first part of this paper, Figure 3 shows that if a large fiscal adjustment is expenditurebased, it is less likely that there will be a government change than if the deficit reduction is tax-based. This result holds both when we look at ALLCH and IDEOCH.

\subsection{Regression Analysis}

In this section we run several regressions which try to predict the likelihood or reappointment of an incumbent government as a function of several political and economic variables, including changes in the deficit, taxes and spending. The bottom line of these regressions is that it is difficult to find any economic variable (with the possible exception of inflation) which is sistematically and robustly correlated with the probability of a government defeat in a election. This holds as well for fiscal variables: we find no evidence that spending cuts, tax increases and deficit reduction policies make it more likely for incumbents to loose.

Our interpretation is that political change is the result of a complex political game and it is hard to pin point stable correlations between economic variables and electoral results. ${ }^{9}$ The important point of our purpose here is precisely that a fiscal adjustment is only one of the many components of such political dynamics and it is not a "deal breaker" so that no matter what else is happening it implies an electoral defeat. If that were the case we should find a correlation between the occurence of fiscal adjustments and electoral losses.

We have tried many specifications of our probit regression in which the left hand side variables are measures of government changes. We first adopted the same specification by Alesina, Perotti and Tavares (1998) and then we explored many others. We first report probit regressions with the variable measuring cabinet change (IDEOCH) as our dependent variable. To study the impact of fiscal adjustments on cabinet change, and to test for the robustness of our results, we use three different measures: the change in non-cyclically adjusted deficit (CHDEF), the change in cyclically adjusted deficit (COCHDEF) and the average change in deficit during the tenure of the current cabinet (TOTCHDEF). In our baseline specification, we also include macroeconomic variables such as the change in real GDP (dGDP), the change in unemployment rate (dUNR) and the inflation rate (INFL). We then use political variables to control for three different

\footnotetext{
${ }^{9}$ For the case of the US in a series of papers Fair $(1978,1982,1988)$ argued that the rate of growth of the economy a few quarters before the election is a critical determinant of presidential elections. For a discussion of this evidence see Alesina and Rosenthal (1995).
} 
characteristics of the cabinet: the number of year the cabinet has been in power (DURAT), whether it is composed of a coalition of parties (COAL) and whether it has the majority in the parliament (MAJ).

Table 2 presents the results of our baseline specification. It shows that the deficit variables are not statistically significant irrespective of the measure we use, suggesting that governments implementing fiscal tightening are on average not penalized at the following election. INFL (the inflation rate) is statistically significant in all regressions. It seems that voters are especially averse to inflation. Brander and Drazen (2008) find a similar result for a different (larger) set of countries and a different (earlier) time period. The coefficients on the other macroeconomic variables are of the sign one would expect, but they are not statistically significant in many specifications. They show that an increase in the growth rate of real GDP reduces the probability of a government change, whereas the unemployment rate has a really small coefficient. The signs of the coefficients on political variables are also generally consistent with conventional wisdom, although only DURAT is statistically significant. As we would expect, the probability of government change increases with the lenght of its tenure.

In Table 3 we extend this baseline specification by including variables in deviation from the weighted average of G7 countries. ${ }^{10}$ Thus we use GDP growth, inflation rate and unemployment rate in deviations from G7 average in every year. The motivation is clear: we test whether voters punish government not for their performance per se but with respect to its performance relative to the "world average". As before, we do not find evidence of a statistically significant relation between the change in fiscal deficit and government change in the direction predicted by the conventional wisdom. No coefficients on deficit variables are statistically significant, as in table 2 . Once again this result is fully consistent with those found by Brander and Drazen (2008). Also when we look at macroeconomic and political variables, our results do not vary substantially from the ones obtained in the previous specification.

In Table 4 we use the same specifications as before but run the regressions only on deficit reduction years. Regressions on this restricted sample allow us to check for the robustness of the results we obtained while considering the full sample, and to assess if the sample of fiscal adjustment years differs significantly. The estimated coefficients on the variables measuring the change of public deficit are not substantially different from those obtained in the previous set of regressions. They are not statistically significant except for CHREV, whose effect on IDEOCH is positive, meaning that a positive change in the size of the public revenue increases the probability of government change. Thus, even when we restrict the analysis to deficit reduction years, there is no evidence that fiscal tightening harms incumbent governments by reducing the probability of their reelection. Coefficients on macroeconomic and political variables do not differ from the previous set of regressions either, showing that in most regressions only the duration of tenure (DURAT) has a statistically significant positive effect on IDEOCH. As before, the results are robust to the inclusion of variables measuring deviations of macroeconomic variables from G7 countries' weighted average values.

In Table 5 we include the variables which control for the composition of the fiscal adjustment. Also we check whether adjustments based on cuts in transfer-payments or in government-wage consumption are associated with a higher probability of cabinet changes. We focus on large adjustments (those such that deficit to GDP is cut by more than 1.5 percentage points from t- 1 to t) and add four variables to control for the composition of the adjustment, namely PEXP, PTAX, PTRF and PCGW: the share of adjustment on total expenditure, total revenues, transfers and government wages respectively. We focus on transfers and wages because results by Alesina Perotti and

\footnotetext{
${ }^{10}$ Weights for each country are calculated using real GDP.
} 
Tavares (1998) suggested that these were the most successful adjustments in terms of a long lasting solubilization of the debt/GDP ratio. They may also be the least popular, at least according to the conventional wisdom.

Although we get statistically insignificant coefficients for all variables of fiscal composition, it is worth spending some more words on the sign of the coefficients associated with the variables. The sign of the coefficient on PEXP, a dummy variable equal to one if the adjustment is large and expenditure based, is negative, meaning that if an adjustment is large and expenditure-based it is associated with a reduction in the probability of a change of government. Similarly, if we look at PTAX, a dummy variable equal to one if the adjustment is large and tax-based, we get a positive coefficient, meaning that it is more likely that there will be a government change if the deficit reduction is based on an increase in taxes. We then analyze PTRF and PCGW, dummy variables associated with large adjustments based on cuts in transfer payments and government-wage consumption respectively. For both variables we get negative and statistically insignificant coefficients, which suggests that if the adjustment is based on cuts in these categories of expenditure, it is less likely that the government will change. When we repeat the analysis using cyclically adjusted deficit (COCHDEF) we obtain similar results ${ }^{11}$.

Finally, if we repeat the same analysis with ALLCH as the dependent variables, we find very similar evidence for variables measuring the change in fiscal deficit. All these results are available from the authors. While the coefficients on macroeconomic and political variables are left unchanged in most of the cases, there are small differences in the coefficients on fiscal deficit variables. When we run the same specification of Table 2 on ALLCH, results are analogous as before. Similarly, when we run the same regressions only on fiscal adjustments years (as we did in Table 4), we get that only the coefficient on TOTCHDEF is different: although it is positive as before, it is not statistically significant.

Lastly, to check the robustness of our results, we run a battery of regressions using logit model and logit fixed effects model, in which we control for country fixed effects (Table 6). The estimations we get are not substantially different from the ones we get in our probit specification. In particular using the same specification of Table 2 and Table 3 the estimations obtained using a logit fixed effects model are consistent with previous results. The evidence suggest that DURAT is positive and statistically significant while INFL is almost always positive but not statistically significant in all the specifications. Once again, none of the deficit variables are statistically significant.

\section{Reverse Causality}

Thus far we uncovered no evidence suggesting that governments which engage in even large fiscal adjustments are systematically voted out of office. A question which comes to mind is one of a sort of "reverse causation." Perhaps those governments which are "strong" are those which can safely engage in fiscal adjustments and they are then reappointed "despite" having been fiscally responsible. Note that the question is not whether or not "stronger" government implement more fiscal adjustments (an issue studied by Alesina Ardagna and Trebbi (2006)) but whether stronger governments which implement fiscal adjustments are more likely to be reelected than weaker governments which implement fiscal adjustments. In other words, a weaker government may have a harder time breaking some impediment to implement reforms, but once it does it, the question is whether it suffers more at the polls than a stronger government.

The difficulty is how to define, ex ante, i.e. before reelection (or loss) what a "strong" government is, in a way which is measurable by the econometricians. Our first measure of

\footnotetext{
${ }^{11}$ Those estimates are not reported in the paper but they are available on request.
} 
strength is whether or not the ruling government is formed by a coalition of parties. The idea is that coalition governments are more likely to suffer from internal disagreements (for decisions that include the nature and size of fiscal adjustments to be implemented) and they may be more likely to fall. The evidence does indeed suggest that the average duration of coalition governments is slightly shorter than single party government. In our sample coalition governments last on average 4.12 years while single party governments last 4.20 years. Besides, if we look at the frequency of government change, we find that the probability of cabinet change is slightly higher $(0.38)$ when a coalition government is in power at election time than when a single party government in charge (0.34). Results are consistent when we analyze the "strength" of a government in terms of the share of votes they received at the election and not in terms of the composition of the executive. Obviously the duration of a government is endogenous to policy choices, therefore coalitions may choose certain policies which are less likely to be unpopular, which is precisely the point debated here.

Our second measure of government stability is a dummy variable equal to one if the party of the executive has an absolute majority in the house(s) with lawmaking powers. This measure seems reasonable since one would expect a government to last longer if it has the majority in all houses. In fact we find that when this is the case (as measured by the variable MAJ), the government lasts on average 4.41 years, whereas for the rest of the observations the average duration is 4.17 years. However, differently from the evidence presented for the coalition variable, we get that governments holding the majority in the houses are more likely to change than the rest (45 percent of cases versus 34 ).

We can then proceed and use the variables defined above to investigate the main issue of this section: are more stable governments more likely to implement fiscal adjustments? Do they do so because they are more likely to be reappointed "despite" they have been fiscally responsible?

Our results show that coalition governments implemented 164 fiscal adjustments, corresponding to roughly 47 percent of total observations for which we had a coalition government, whereas single party governments implemented 130 fiscal adjustments, i.e. they did it in 51 percent of the years in which they were governing. If we only look at "large" fiscal adjustments results are similar with previous ones. Coalition governments implemented 34 large fiscal adjustments, corresponding to roughly 9.8 percent of total observations for which we had a coalition government, whereas single party governments implemented 26 fiscal adjustments, that is to say 10.3 percent of the years in which they were governing. If we then look at the stability of the government as measured by the majority in the houses, we find similar differences between governments with an absolute majority and government without an absolute majority in the houses when we look at large fiscal adjustments. The former implemented large adjustments in 10.2 percent of cases, the latter in 10.1 percent of cases. When instead we look at all adjustments the difference is not so clear cut. Governments with the majority implemented 62 fiscal adjustments, which represent 48.8 percent of the years where a government with an absolute majority was in charge. Government without the majority implemented 229 fiscal adjustments, about 49.2 percent of the total (the results are reported in Table 7). So according to our, admittedly imperfect, measure of "strength" it seems that "strong" governments implement fiscal adjustments only slightly more often than average.

Moreover the evidence provided in figures 4 to 7 does not always suggest that more stable governments implementing fiscal adjustments before the election were more likely to be reappointed. For example figure 5 shows that if single party governments implemented fiscal adjustments (in particular small ones) three years before the election they were more likely not to be reelected than if coalition governments did so. Similarly, governments with an absolute majority in the houses were associated with government 
change in 41 percent of cases if they implemented fiscal adjustments one year before the election, compared to 30 percent in the rest of our sample (see figure 7).

The idea that more stable governments are not more protected from government change after they perfom a fiscal adjustment is also supported by the set of regressions we show in Tables 8 and 9. We add interaction variables to the baseline specification described above and try to capture the specific effect on government change associated with more stable governments implementing fiscal adjustments. Even in this specification there is no statistically significant difference between coalition and single party governments implementing fiscal adjustments on the prospect of being reelected. In column 4 of table 8 , where we use a cyclically adjusted deficit variable, we do not find a statistically significant difference between coalition and single party governments. Similarly in column 6 , when we construct a variable interacting TOTCHDEF and COAL, we do not find any statistically significant effect of this variable on the dependent variable IDEOCH.

The evidence that "stronger" governments are not necessarily more protected from electoral turnover is also supported by our results in Table 9 . In all specifications where we include an interaction variable between the deficit variable and a dummy for the government having majority support in the parliament, we don't get statistically significant estimates for the coefficients on the interaction variable.

\subsection{Discussion}

If it is the case that certain types of fiscal adjustments are not necessarily costly in terms of lost output or lost votes, why are they often delayed and politicians reluctant to implement them?

There are two possible, related reasons. The first is that "vote-counting" is not the only political factor at play. Certain constituencies may be able to "block" adjustments to continue receiving rents from government spending because they have enough political energy (time, organization, money). This is sometimes referred to as an issue of diffuse benefits and concentrated costs. For example, in some cases strikes of public-sector employees may create serious disruptions. Pensioners' lobbies may be able to persuade politicians not to touch their pension systems even when future generations will suffer the costs of delayed reforms. Lobbyists for certain protected sectors use campaign contributions for continued protection.

A second and related problem is what Alesina and Drazen (1990) modeled as a "war of attrition" political game. Political conflicts over the allocation of costs of the budget cuts or tax increases, for example, lead to a stalemate that requires time to be resolved. Postponing an adjustment may be costly, but all sides hope to be able to shield themselves from such costs, and the "war" continues until one side gives in. Thus, more polarized political systems and fractionalized societies, where "deals" and compromises are more difficult to reach quickly, should have a harder time stabilizing. Another implication is that a political consolidation of a stable and secure cohesive majority may be a precondition for a fiscal consolidation. Finally, this model is consistent with the "crisis hypothesis," namely that the idea that a sharp deterioration of the economic situation may lead to reforms. In this case, a fiscal consolidation occurs simply because it becomes too costly to continue to postpone. 


\section{Case Studies}

There is great variety of politico- economic features in large fiscal adjustments. They are the result of complex interactions between fiscal, macroeconomic, structural reforms and political variables. In this section we again focus on episodes of large fiscal adjustments, and try to isolate some "interesting" cases. We consider different political environments in order to guarantee the appropriate variety. First we look at Canada in the 1990s, as it can be taken as an example of "strong" government implementing fiscal adjustments. The Liberal Party's share of votes in 1993 was really high, with more than 40 percent of the electors voting for the party. The second case we look at is Finland between 1993 and 1998. This case is completely different, given the proportional and very fragmented political system, in which the government in charge is often a coalition. Thirdly, we focus on Sweden between 1994 and 2000. The Sweden case has some macroeconomics analogies with the Finnish one, as both Sweden and Finland went through a severe financial crisis at the beginning of the 90s. They also present some differences. In Sweden, the Social Democratic Party had a consensus that lasted longer than in Finland: it took office in 1994 and started the fiscal consolidation just right after the election, holding the majority until the 2006 elections. Finally we consider the United Kingdom in the 1990s, which gives us a good example of a situation in which fiscal adjustments were implemented but the government wasn't re-elected.

The empirical evidence suggests that in the cases of re-elections, the government suffers a small decrease in the share of votes in the election following the consolidation program, but this does not prevent them from staying in charge (for example in Finland). In some cases the voters seem to appreciate the consolidation as time goes by, and after a small decrease in the share of votes, a bigger increase follows (as in Canada).

\subsection{Canada 1993-1997: Expenditure-Based Adjustment with Gov- ernment Re-election}

Canada experienced a severe economic downturn in the early 1990s which had a significant impact on the country's budget balance. In 1992 public spending rose well above 50 percent of GDP and the budget deficit increased from 4.6 percent of GDP in 1989 to 9.1 percent in 1992. As a consequence, the public debt-to-GDP ratio grew sharply to above 100 percent of GDP. The worsening of the overall general government deficit originated in the deficit of the provinces (Hauptmeier et al. 2006). Moreover other key elements contributed such as the substantial competitive disadvantages that Canada faced because of high labor costs, low productivity growth rates, and a pronounced exchange rate appreciation that started in the mid-eighties.

In reaction to these events, in 1993 the Canadian government started an ambitious austerity program. The success was particularly based on three elements: low and stable inflation, structural reforms, and substantial expenditure reductions. By 1997, the budget had been balanced. More than 90 percent of the fiscal adjustment was due to spending cuts. The main expenditure measures included "cuts in wages (in particular, public employee compensation), unemployment benefits, defense spending, health care services, agricultural and business subsidies, and transfers to provinces and households" (Leigh et al. 2007). As a result, total and primary expenditures declined by around 3.5 percent of GDP within the first two years. In the following years the consolidation path was continued and led to a total spending decrease by more than 11 percent of GDP over seven years, compared to the peak it reached in 1992.

On the revenue side some reforms lowered the tax burden and improved the fairness of the tax system, reducing personal income taxes at the provincial level, increasing corporate income tax rates, and broadening the base of both. Other measures included 
a wide use of privatizations and a reformation of transfer systems, which benefited both the budget balance and the supply side of the economy. Some major reforms were also introduced to increase labor market flexibility and to make the financial sector more competitive and efficient. For instance, the financial services sector policy was reviewed and reformed in the late 1990s.

Traditionally, politically Canada had a two-party system with the Conservative and Liberal parties dominating the political scene.

Beginning in the 1990s, Canadian national politics became more like of a multi-party system, even though the Liberal and Conservative parties kept a relatively dominant role. But in 1993 a total of five main political parties competed for electoral support, and an erosion of the command enjoyed by the Liberal and Conservative parties. In 1993 the Liberal Party took office, running its election campaign explicitly on a platform of addressing Canada's fiscal issues (the so-called "Red book"). The party was able to win a strong majority, one of the best results in Canada's history, after being out of power since 1984. In the 1993 elections, the party won 177 seats and achieved the third-best performance in its history, and its best performance since 1949. The Liberal Party was re-elected with a considerably lower majority in the following general election in 1997, but nearly tied their 1993 result in the subsequent 2000 election. Chretien became the only Canadian Prime Minister to win three consecutive majority governments.

\subsection{Finland 1993-1998: Expenditure Based Adjustment with Government Re-election}

During the 1980s Finland went through a financial liberalization process that led to a lending boom. The boom was followed by a recession, partially due to the banking crisis of 1991, and partially due to the deterioration of the terms of trade following the fall of the Soviet Union, which accounted for 15 to 20 percent of Finland's foreign trade. Finland's real GDP dropped by about 14 percent between 1990 and 1993 . By 1994 unemployment had reached nearly 20 percent. ${ }^{12}$. Government spending over GDP reached a staggering 65 per cent and the deficit exceeded 7 percent. At the same time, bailout costs for the banking sector further accelerated the increase in the public debt ratio.

The government reaction was to enact a substantial fiscal adjustment over 6 years, between 1993 and 1998: the debt over GDP ratio went down of a cumulative 6.2 percentage points between 1993 and 1998. We estimate that about 78 percent of the adjustment was due to expenditure cuts. According to Hauptmeier et al. (2006) there was a 5 percent of GDP reduction in total expenditures over the first 2 years of the fiscal adjustment and that expenditures were reduced by 15 percent to 49 percent of GDP over seven years. Furthermore in the same period, the fiscal balance improved substantially to achieve a 7 percent surplus by the end of the 1990s. The main expenditure measures included cuts in social benefits, particularly unemployment benefits, transfers to municipalities, subsidies, wages, and capital spending. For instance, contractual pay increases were frozen for 4 years starting from 1991, and those measures were accompanied by moderate wage agreements in the public sector and reductions in public sector employment levels. The government also implemented broadly revenue-neutral tax reform raising user fees in health and education, along with increases in payroll taxes and in employee compensation for social security. Complementary reform measures also helped the fiscal adjustment. For instance, 'incomes policy agreements' were implemented on a biannual basis, contributing to wage stability and low levels of inflation. A devaluation of the exchange rate in 1992 also helped improve the budget balance by benefitting the

\footnotetext{
${ }^{12}$ For more details see Honkapohja and Koskela (1999)
} 
tradable sector. Furthermore, inflation targeting at 2 percent contributed to the overall stability and renewed growth of the economy in the following years.

Finland can be classified as a case of expenditure-based fiscal adjustment with reelection if we look at the 1999 elections. The result is not as clear-cut as it was for Canada since there was a change in the Finnish government in the 1995 elections, after the austerity program had already started. The Finnish political background in the 1990s can be illustrated as follows. The Centre Party and the Social Democratic Party were the two main political parties between 1993 and 1998, and both implemented austerity policies during that period. In 1992, the Centre-Party government elected in 1991 started a fiscal consolidation program based on a new medium-term framework. It lost the following elections, in April 1995, when the SDP won with 28.3 percent of the votes and immediately introduced an austerity package. In particular the new social-democratic government was formed by a five-party "Rainbow Coalition" and Paavo Lippon en, the SDP leader, was appointed Prime Minister. The SDP was re-elected in 1999, although by a very narrow majority, having lost a significant share of the votes (5.4 percent) relative to the previous election. According to election results, there was a strong political competition among three parties between 1995 and 2003: the SDP, the National Coalition Party, and the Centre Party, with the latter taking office again after the 2003 elections. As in Canada, from electoral results we can see a decrease in votes for the leading political party during the fiscal adjustment. Still, the SDP, which had the majority in 1992, again had the relative majority in the 1999 elections.

\subsection{Sweden 1994-2000: Expenditure-Based Adjustment with Gov- ernment Re-election}

The boom of the 1980s in Sweden was followed by a recession, which was triggered by the banking crisis of 1991, after the collapse of a real estate bubble. The public expenditure ratio had increased to 73 percent of GDP in 1993 and public debt had risen rapidly to over 70 percent of GDP. The budget deficit was at 11.2 percent of GDP and the unemployment rate at 7.5 percent. In response to these events, the Swedish government started a fiscal consolidation program, which, according to our estimates, led to a cumulative fiscal adjustment of 8.4 percent over 7 years mainly because of substantial cuts in expenditures. By the end of the year 2000 ther was a 3 per cent of GDP surplus.

Around 70 percent of the adjustment was based on cuts in expenditures. Central features of the new budget process, implemented in January 1997, were also a budgetary process with multi-year expenditure ceilings and a medium-term target for the government's net lending. An expenditure ceiling was imposed in 1996, which limited central government expenditures and expenditures for the pension system outside the budget (but did not include interest expenditures). The adjustment covered approximately twothirds of the total Swedish general government expenditures and substantially reduced government transfers, such as pensions, early retirement benefits, housing subsidies, and social and unemployment insurance. Moreover, cuts across on a broad range of spending programs were implemented between 1994 and 2000. Some revenue measures were also introduced, including increases in social security fees, full taxation of dividends and capital gains, and increases in personal income tax rates. Hauptmeier et al. (2006) report that since mid-1995, "the government gradually implemented a pension reform and introduced a funded pillar, besides pursuing a privatization program and a higher degree of labour market liberalization".

Sweden, as was the case for Canada and Finland, is a case of expenditure-based fiscal adjustment with re-election. In the September 1994 general election the Social 
Democratic Party won most seats, although not an overall majority, and Ingvar Carlsson returned to power at the head of a minority government after a center-right minority government had won the previous elections in the early 1990s. In August of 1995 Carlsson announced that he would step down as prime minister in March 1996, once his party had chosen a replacement. In the meanwhile, a referendum was passed in November 1994 supporting Sweden's application for entering the European Union (EU), and in January 1995 Sweden became a full EU member.

Göran Persson, the former Sweden finance minister, replaced Carlsson as prime minister in March 1996 and continued the austerity measures that started at the beginning of the 1990s. Although the fiscal adjustment was quite significant as dicussed above Persson's Social Democrats finished ahead in the September 1998 general election, although its share of votes decreased by 7 percent to 38 percent. The votes for the Social Democratic Party were lost to the ex-communist Left Party, which doubled its vote to 12 percent between 1994 and 1998, and which supported the government conditional on it raising welfare spending and holding a referendum to join the Euro. Between 1998 and 2002, the economy started growing again, which enabled tax cuts and led to the Social Democratic victory in the following general elections in 2002. The Social Democrats held office until 2006.

\subsection{United Kingdom 1994-1999: Expenditure-Based Adjustment without Government Re-election}

On September 16, 1992, the Prime Minister Major was forced to withdraw the pound from the European Exchange Rate Mechanism because the British government could not maintain the value of the currency at agreed-upon levels. In early 1993, ther was positve growth driven by an increase in private consumption. Unemploymeny fell over the following years, while inflation remained relatively low. At the same time austerity measures were implemented, mostly through expenditure cuts. Using our data, we estimate that the United Kingdom experienced a cumulative decline in the ratio of deficit to GDP of 6.7 percentage points between 1994 and 1999, and that almost 60 percent of the fiscal adjustment was due to expenditure cuts. Expenditure measures mainly consisted of sustantial cuts in government consumption, public employment and transfers. They also implemented cuts in defense, transport and social benefits (by setting tighter eligibility criteria). On the revenue side the austerity program included increases in indirect taxes and some duties. However "The VAT was lowered on some items for equity reasons, advanced corporation tax rebates were abolished, and there was a small reduction in the corporate tax rate" (Leigh et al. 2007). Complementary measures were also implemented, and they included establishing the independence of the Bank of England, reforming the tax systems, in particular in the area of corporate taxation, and social contributions especially in the low-wage sector. Moreover legislation on corporate governance and competition was improved, and the utilities sector was substantially reformed by changing regulations.

In the election of 1997 the Conservative Party lost and the Labour Party took office. It should be remembered tat after three consecutive victories, the Conservative Party won again in 1992, but this time by a narrower margin: the Tory majority in 1992 was reduced from over a hundred seats to below thirty. In addition the economic credibility of the government was seriously undermined a few months after the election, when Major was forced to withdraw the pound from the European Exchange Rate Mechanism. 


\section{Conclusion}

In this paper we have examined in some details the evidence supporting the conventional wisdom that fiscally "tight" governments loose popularity and elections and fiscally expansionary ones win. We found surprisingly little evidence supporting this conventional wisdom given the strenght with which this view is held by politicians, commentators, political scientists and economists. More precisely we found no evidence that even large reductions of budget deficits are associated always ( or most of the times) with electoral losses .

The biggest counter argument is one of reverse causation, namely strong and popular government can implement fiscal adjustment and be reelected "despite" such policies, thus only these government do so. Our attempts to uncover these reverse causation does not provide convincing evidence that our result are only driven by this effect. Needless to say it is difficult to measure "strength" of a government, ex ante, and therefore our test should be taken cautiously. But we believe that a cautious conclusion is warranted: reasonably solid governments not on the verge of losing an election anyway can engage in fiscal adjustments, even aggressive ones and survive the next election.

Three case studies of sharp fiscal adjustments (Canada, Finland and Sweden) show a decline in political support for the government, but a strong recovery later on. In the case of the UK the political revieval did not occur and a very unpopular John Major lost. 


\section{Appendix}

\subsection{National Accounts Data}

Fiscal and macroeconomic data are taken from the OECD Economic Outlook Database no.84. In our analysis we focus on the period 1975-2008. Variables we use in our study are defined as follows:

$\boldsymbol{C H} \boldsymbol{E X P}$ : Change in public expenditures: percentage point change in the ratio of primary expenditures to GDP. Primary expenditures are computed as government current disbursements less gross government interest payments.

CHREV : Change in public revenues: percentage point change in the ratio of public revenues to GDP. Public revenues are computed as governement current receipts less gross governemnt interest receipts.

$\boldsymbol{C H D E F}$ : Change in public deficit: percentage point change in the ratio of public deficit to GDP. Calculated as $C H E X P$ less $C H R E V$.

CH TRF : Change in transfers to households: percentage point change in the ratio of transfers to households to GDP.

$\boldsymbol{C H S U B}$ : Change in subsidies: percentage point change in the ratio of subsidies to GDP.

COCHEXP : Change in government expenditures $(C H E X P)$, corrected for the cycle: percentage point change in the ratio of cyclically adjusted primary expenditures to potential GDP.

COCH REV : Change in government revenues (CHREV), corrected for the cycle: percentage point change in the ratio of cyclically adjusted government revenues to potential GDP.

COCHDEF : Change in the primary deficit $(C H D E F)$, corrected for the cycle: calculated as COCHEXP less COCHREV.

TOTCHDEF : Average change in deficit during tenure: average percentage point change in the deficit over the years that the current cabinet has been in power, up to the current year. That is the average of $C H D E F$ for the years from the last termination up to the current year.

$\boldsymbol{\Delta G D P}$ : Rate of growth of real GDP, percent. Computed as the percentage change of the variable "Gross domestic product, volume, at 2000 ppp".

$\Delta$ TOTGDP : Average growth during tenure: average growth rate from the time when a cabinet came to power, up to current year, percent.

$\Delta$ GDPG7 : Growth of G7 countries: weighted average growth rate of the G7 countries, percent. Weights for each country are calculated using real GDP.

$\Delta \boldsymbol{G D P g} 7$ : Growth relative to the G7 countries: calculated as $\triangle G D P$ less $\triangle G D P G 7$. $\boldsymbol{U N R}$ : Unemployment rate, percent.

$\boldsymbol{\Delta} \boldsymbol{U N} \boldsymbol{R}:$ Growth of the unemployment rate, percent: $\left[\left(U N R_{t} / U N R_{t-1}\right)-1\right] * 100$.

$\Delta$ TOTUNR : Average unemployment growth during tenure: average annual growth rate of unemployment rate from beginning of cabinet's tenure to current year, percent.

UN Rg7 : Unemployment rate relative to the G7 countries: unemployment rate less the GDP-weighted average of the G7 unemployment rate, percentage points.

INFL : Inflation: rate of change of the GDP deflator, percent. It is constucted using the variable "Gross domestic product, deflator, market prices".

TOTINFL : Average inflation during tenure: average rate of inflation from the beginning of cabinet's tenure to current year, percent.

I NFL $\mathbf{F} 7$ : Inflation rate relative to the G7 countries: inflation rate less the GDPweighted average of the G7 inflation rate, percentage points. 
$\boldsymbol{P E X P}$ : Spending-based adjustment: dummy variable equal to 1 when following two conditions hold:

a. there is a large adjustment $(C H D E F<-1.5)$;

b. $C H E X P$ is less than its median across all years in which a large adjustment occurs.

$\boldsymbol{P T A X}$ : Tax-based adjustment: dummy variable equal to 1 when following two conditions hold:

a. there is a large adjustment $(C H D E F<-1.5)$;

b. CHREV is more than its median across all years in which a large adjustment occurs.

$\boldsymbol{P T R F}$ : Transfer-based adjustment: dummy variable equal to 1 when following two conditions hold:

a. there is a large adjustment $(C H D E F<-1.5)$;

b. CHTRF is less than its median across all years in which a large adjustment occurs.

PCGW : Government wage-based adjustment: dummy variable equal to 1 when the following two conditions hold:

a. there is a large adjustment $(C H D E F<1.5)$;

b. $C H C G W$ is less than its median across all years in which a large adjustment occurs.

NIN TRTg7 : Relative nominal interest rate: long term nominal interest rate (tenyear treasury notes) of a given country less the GDP-weighted average of long nominal interest rates in the $\mathrm{G} 7$ countries, percentage points.

RIN TRT : Real interest rate: ten-year interest rate minus the growth rate of the GDP deflator, percent.

$\boldsymbol{R I N T R T g 7}$ : Relative real interest rate: ten-year real interest rate of a given country less the GDP-weighted average of real interest rates in the G7 countries.

\subsection{Cabinet data}

For cabinet data we use the Database of Political Institutions (DPI) 2009. Again, we cover the period 1975-2008. The cabinet variables we focus on are defined as follows:

TERM : Government termination: dummy variable equal to 1 in any year in which a government ends, regardless of the reason. A termination may or may not involve a "change" in cabinet ideology or prime minister.

DURAT : Duration: integer number of years that a cabinet has been in power, up to the current year. A cabinet that falls during its first year in power is counted as 1. Every time there is a government termination $(T E R M=1), D U R A T$ is reset to 1 the year after the termination.

SING : Single party: dummy variable equal to 1 if a single party cabinet is in power. COAL : Coalition: dummy variable equal to 1 if a coalition cabinet (including ministers from two or more parties) is in power.

$\boldsymbol{M A J}$ : Majority: dummy variable equal to 1 if the cabinet has majority support in parliament. 
IDEOCH : Change in ideology of cabinet: dummy variable equal to 1 if there is a change in the ideology index between the current year and the next. It is constructed by exploiting the change in the value of variable $E X E C R L C$ (describing the ideology of the chief executive's party) in the DPI dataset.

ALLCH : Change of ideology or prime minister; dummy variable equal to 1 if either $I D E O C H$ or $P M C H$ is equal to 1.

\section{References}

[1] Alcidi, Cinzia and Daniel Gros (2010) "The European experience with large fiscal adjustments", VoxEU.org, 28 April.

[2] Alesina, Alberto and Ardagna Silvia (2010) "Large Changes in Fiscal Policy: Taxes Versus Spending", forthcoming in Tax Policy and The Economy.

[3] Alesina, Alberto, Silvia Ardagna and Francesco Trebbi (2006) "Who Adjusts and When? On the Political Economy of Reforms," NBER Working Papers 12049

[4] Alesina, Alberto and Allan Drazen (1991) "Why are Stabilizations Delayed?," American Economic Review, 81, 1170-1188.

[5] Alesina, Alberto, Roberto Perotti and Josè A. Tavares (1998) "The Political Economy of Fiscal Adjustments", Brookings Papers on Economic Activity, Spring.

[6] Alesina, Alberto and Howard Rosenthal (1995) "Partisan Politics, Divided Government and the Economy",Cambridge, UK: Cambridge University Press.

[7] Bonfiglioli, Alessandra and Gino Gancia (2010) "Politicians, Uncertainty and Reforms" unpublished

[8] Brender, Adi and Allan Drazen (2005) "Political budget cycles in new versus established democracies", Journal of Monetary Economics, Elsevier, vol. 52(7), pages 1271-1295, October

[9] Brender, Adi and Allan Drazen (2008) "How Do Budget Deficits and Economic Growth Affect Reelection Prospects? Evidence from a Large Panel of Countries", American Economic Review, 98(5): 2203-20

[10] Buti, Marco and Paul Van den Noord (2004a) "Fiscal Policy in EMU: Rules, Discretion and Political Incentives", Moneda y Crédito, No. 218 (2004), pp. 265-31

[11] Buti, Marco and Paul Van den Noord (2004b) "Fiscal Discretion and Elections in the Early Years of EMU", Journal of Common Market Studies, Vol. 42, No. 4 (2004), pp. $737-756$

[12] Buti, Marco, Alessandro Turrini, Paul Van den Noord and Pietro Biroli (2008) "Defying the 'Juncker Curse': Can Reformist Governments Be Re-elected?" , Empirica, Springer, vol. 36(1), pages 65-100, February.

[13] Buti, Marco, Alessandro Turrini, Paul Van den Noord and Pietro Biroli (2010) "Reforms and re-elections in OECD countries", Economic Policy, 25: 61-116

[14] Drazen, Allan (2000) "Political Economy in Macroeconomics" Princeton, NJ: Princeton University Press 
[15] Fair, Ray C. (1978) "The Effect of Economic Events on Votes for President," Review of Economics and Statistics 60, 159-72.

[16] Fair, Ray C. (1982) "The Effect of Economic Events on Votes for President: 1980 Results," Review of Economics and Statistics 64, 322-25.

[17] Fair,Ray C. (1988) "The Effects of Economic Events on Votes for President: 1984 Update," Political Behavior 10, 168-79.

[18] Giavazzi, Francesco and Marco Pagano (1990) "Can Severe Fiscal Contractions Be Expansionary? Tales of Two Small European Countries", NBER Macroeconomics Annual, MIT Press:95-122.

[19] Giorno, Claude, Pete Richardson, Deborah Roseveare, and Paul van den Noord (1995), "Potential Output, Output Gaps, and Structural Budget Balances," OECD Economic Studies, No. 24, 167-209.

[20] Hauptmeier, Sebastian, Martin Heipertz and Ludger Schuknecht (2006), Expenditure reform in industrialised countries: a case study approach, Working Paper Series No 634, May 2006

[21] Honkapohja,Seppo and Erkki Koskela (1999), "The economic crisis of the 1990s in Finland," Economic Policy, vol. 14(29), pages 399-436, October.

[22] International Monetary Fund (2010), World Economic Outlook, Washington DC September

[23] Leigh,Daniel, Alexander Plekhanov and Manmohan S. Kumar (2007),"Fiscal Adjustments: Determinants and Macroeconomic Consequences,"IMF Working Papers 07/178, International Monetary Fund.

[24] Perotti, Roberto (2011), "The "Austerity Myth":Gain Without Pain?"

[25] Persson, Torsten and Guido Tabellini (2000), "Political Economics: Explaining Economic Policy", MIT Press, Cambridge and London.

[26] Rogoff, Kenneth and Anne Sibert (1988), "Elections and Macroeconomic Policy Cycles," Review of Economic Studies 55, 1-16. 
Table 1 - 10 periods with largest cumulative fiscal adjustment (cyclically adjusted variables)

\begin{tabular}{|c|c|c|c|c|c|c|c|c|c|c|}
\hline COUNTRY & YEARS & $\begin{array}{l}\text { NUMBER } \\
\text { OF YEARS } \\
\end{array}$ & $\begin{array}{l}\text { CHANGE IN } \\
\text { CYCL. ADJ. } \\
\text { DEFICIT } \\
\text { (COCHDEF) } \\
\end{array}$ & $\begin{array}{l}\text { CHANGE IN CYCL. } \\
\text { ADJ. } \\
\text { EXPENDITURES } \\
\text { (COCHEXP) } \\
\end{array}$ & $\begin{array}{l}\text { CHANGE IN } \\
\text { CYCL. ADJ. } \\
\text { REVENUES } \\
\text { (COCHREV) }\end{array}$ & $\begin{array}{l}\text { CUMULATIVE } \\
\text { FISCAL } \\
\text { ADJUSTMENT } \\
\end{array}$ & $\begin{array}{c}\text { FISCAL } \\
\text { ADJUSTMENT } \\
\text { PER YEAR } \\
\end{array}$ & $\begin{array}{l}\text { \% OF FISCAL ADJ. } \\
\text { DUE TO CUT IN } \\
\text { EXPENDITURES }\end{array}$ & TERM & $\begin{array}{l}\text { CHANGE IN } \\
\text { IDEOLOGY }\end{array}$ \\
\hline DENMARK & $1983-86$ & 4 & -2.43 & -0.85 & 1.58 & -9.74 & -2.43 & 35.03 & 2 & 0 \\
\hline GREECE & $1990-94$ & 5 & -1.88 & -0.50 & 1.38 & -9.39 & -1.88 & 26.38 & 2 & 1 \\
\hline SWEDEN & $1994-2000$ & 7 & -1.20 & -0.81 & 0.38 & -8.38 & -1.20 & 67.91 & 3 & 0 \\
\hline BELGIUM & $1982-87$ & 6 & -1.26 & -0.96 & 0.30 & -7.57 & -1.26 & 76.50 & 2 & 0 \\
\hline CANADA & $1993-97$ & 5 & -1.36 & -1.25 & 0.11 & -6.80 & -1.36 & 91.80 & 1 & 0 \\
\hline UNITED KINGDOM & 1994-99 & 6 & -1.12 & -0.66 & 0.47 & -6.72 & -1.12 & 58.45 & 1 & 1 \\
\hline FINLAND & 1993-98 & 6 & -1.04 & -0.81 & 0.23 & -6.23 & -1.04 & 78.13 & 2 & 1 \\
\hline PORTUGAL & $1982-84$ & 3 & -1.89 & -1.14 & 0.75 & -5.67 & -1.89 & 60.16 & 2 & 2 \\
\hline ITALY & $1990-93$ & 4 & -1.24 & 0.13 & 1.36 & -4.95 & -1.24 & -10.21 & 2 & 1 \\
\hline IRELAND & $1986-89$ & 4 & -1.21 & -1.54 & -0.33 & -4.82 & -1.21 & 127.50 & 2 & 1 \\
\hline
\end{tabular}

Source: Authors' calculations on OECD Economic Outlook Database no.84 and DPI 2009. 
Figure 1 - Frequency in cabinet changes and fiscal adjustments

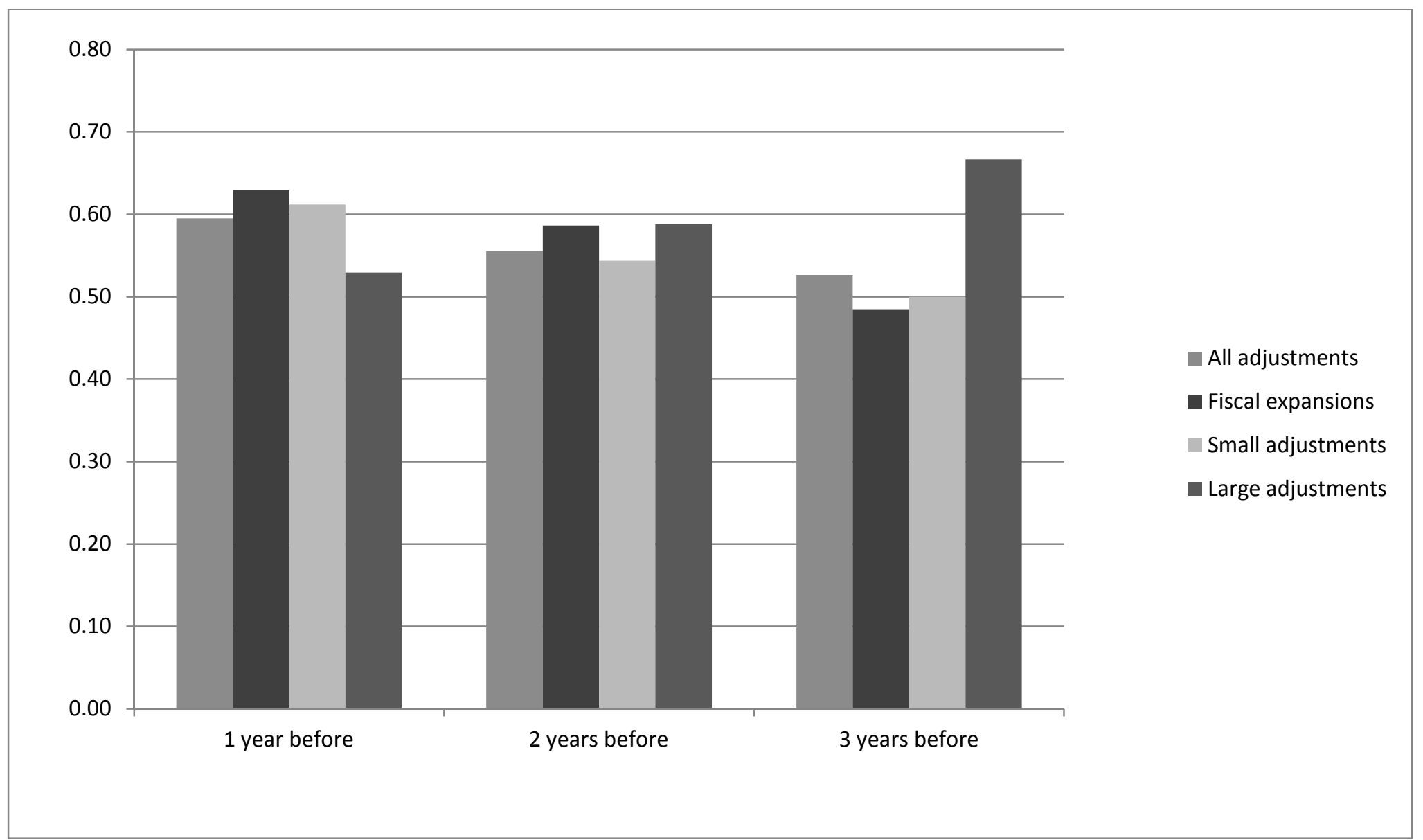

Source: Authors' calculations on OECD Economic Outlook Database no.84 and DPI 2009. 
Figure 2 - Frequency in changes of cabinet ideology and fiscal adjustments

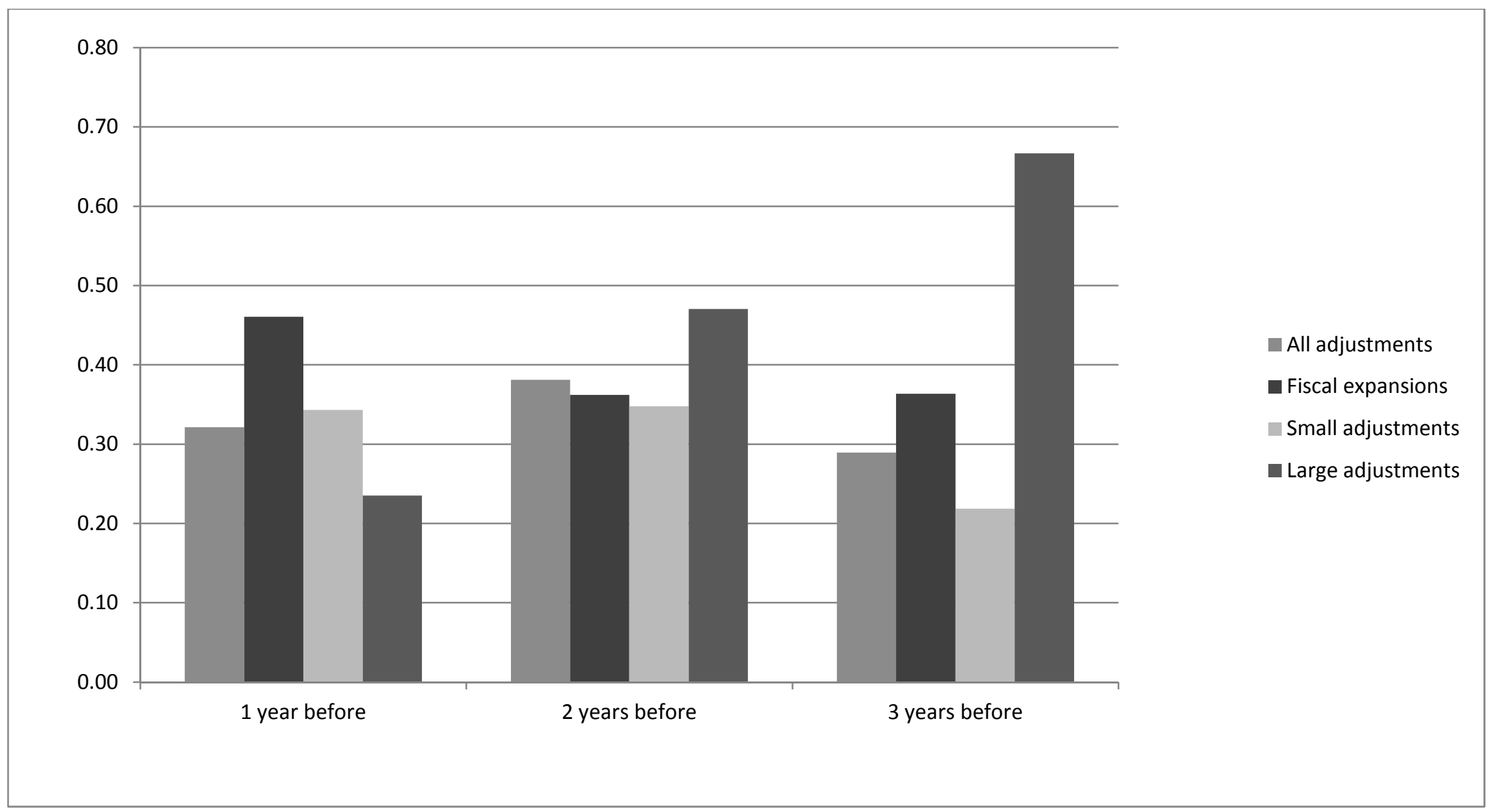

Source: Authors' calculations on OECD Economic Outlook Database no.84 and DPI 2009. 
Figure 3 - Frequency in changes of cabinet ideology and cabinet changes given expenditure/tax based adjustments

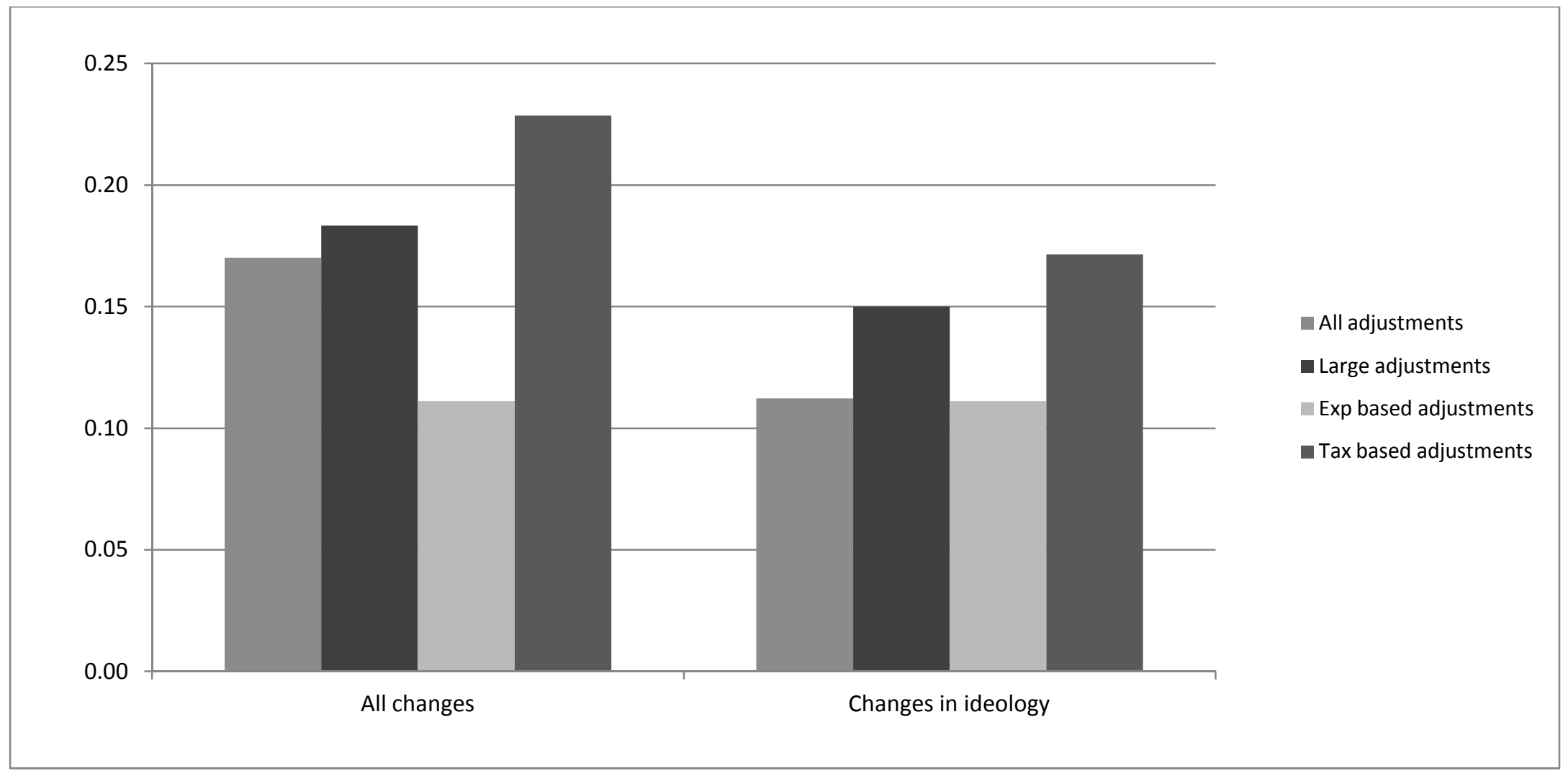

Source: Authors' calculations on OECD Economic Outlook Database no.84 and DPI 2009. 
Table 2 - Probit coefficients (full sample)

\begin{tabular}{|c|c|c|c|c|c|}
\hline VARIABLES & $\begin{array}{c}\text { (1) } \\
\text { IDEOCH }\end{array}$ & $\begin{array}{c}\text { (2) } \\
\text { IDEOCH }\end{array}$ & $\begin{array}{c}\text { (3) } \\
\text { IDEOCH }\end{array}$ & $\begin{array}{c}\text { (4) } \\
\text { IDEOCH }\end{array}$ & $\begin{array}{c}\mathbf{( 5 )} \\
\text { IDEOCH }\end{array}$ \\
\hline CHDEF $^{1}$ & $\begin{array}{l}-0.0627 \\
(0.052)\end{array}$ & & & & \\
\hline COCHDEF $^{2}$ & & $\begin{array}{l}0.0039 \\
(0.056)\end{array}$ & & & \\
\hline TOTCHDEF $^{3}$ & & & $\begin{array}{l}-0.0100 \\
(0.067)\end{array}$ & & \\
\hline CHEXP $^{4}$ & & & & $\begin{array}{l}-0.0344 \\
(0.063)\end{array}$ & \\
\hline CHREV $^{5}$ & & & & & $\begin{array}{l}0.0551 \\
(0.061)\end{array}$ \\
\hline DGDP & $\begin{array}{l}-0.0471 \\
(0.042)\end{array}$ & $\begin{array}{l}-0.0439 \\
(0.044)\end{array}$ & $\begin{array}{c}-0.1039 * * \\
(0.048)\end{array}$ & $\begin{array}{l}-0.0499 \\
(0.044)\end{array}$ & $\begin{array}{l}-0.0320 \\
(0.042)\end{array}$ \\
\hline DUNR & $\begin{array}{l}0.0009 \\
(0.005)\end{array}$ & $\begin{array}{l}-0.0030 \\
(0.005)\end{array}$ & $\begin{array}{l}-0.0066 \\
(0.006)\end{array}$ & $\begin{array}{l}-0.0007 \\
(0.005)\end{array}$ & $\begin{array}{l}-0.0005 \\
(0.005)\end{array}$ \\
\hline INFL & $\begin{array}{c}0.0266 * * \\
(0.013)\end{array}$ & $\begin{array}{c}0.0342^{* *} \\
(0.014)\end{array}$ & $\begin{array}{c}0.0309 * * \\
(0.013)\end{array}$ & $\begin{array}{c}0.0301^{* *} \\
(0.013)\end{array}$ & $\begin{array}{c}0.0265^{* *} \\
(0.013)\end{array}$ \\
\hline DURAT & $\begin{array}{c}0.2265 * * * \\
(0.050)\end{array}$ & $\begin{array}{c}0.2273 * * * \\
(0.052)\end{array}$ & $\begin{array}{c}0.2295^{* * *} \\
(0.051)\end{array}$ & $\begin{array}{c}0.2246 * * * \\
(0.050)\end{array}$ & $\begin{array}{c}0.2256^{* * *} \\
(0.050)\end{array}$ \\
\hline COAL & $\begin{array}{l}0.0547 \\
(0.150)\end{array}$ & $\begin{array}{l}0.0493 \\
(0.154)\end{array}$ & $\begin{array}{l}0.0450 \\
(0.152)\end{array}$ & $\begin{array}{l}0.0626 \\
(0.150)\end{array}$ & $\begin{array}{l}0.0644 \\
(0.150)\end{array}$ \\
\hline MAJ & $\begin{array}{l}0.0039 \\
(0.178)\end{array}$ & $\begin{array}{l}-0.0154 \\
(0.182)\end{array}$ & $\begin{array}{l}-0.0467 \\
(0.179)\end{array}$ & $\begin{array}{l}-0.0083 \\
(0.178)\end{array}$ & $\begin{array}{l}0.0084 \\
(0.178)\end{array}$ \\
\hline Constant & $\begin{array}{c}-1.7700 * * * \\
(0.230)\end{array}$ & $\begin{array}{c}-1.8006^{* * *} \\
(0.242)\end{array}$ & $\begin{array}{c}-1.6166^{* * *} \\
(0.237)\end{array}$ & $\begin{array}{c}-1.7657^{* * *} \\
(0.234)\end{array}$ & $\begin{array}{c}-1.8195^{* * *} \\
(0.230)\end{array}$ \\
\hline $\begin{array}{l}\text { Log-likelihood } \\
\text { Observations }\end{array}$ & 613 & 591 & 613 & 614 & 613 \\
\hline
\end{tabular}

Source: see data Appendix at the end of the paper.

Standard errors in parentheses: $* * * p<0.01, * * p<0.05, * p<0.1$.

1. Change in public deficit: percentage point change in the ratio of public deficit to GDP.

2. Change in the primary deficit (CHDEF), corrected for the cycle.

3. Average change in deficit during tenure: average percentage point change in the deficit over the years that the current cabinet has been in power, up to the current year.

4. Change in public expenditures: percentage point change in the ratio of primary expenditures to GDP.

5. Change in public revenues: percentage point change in the ratio of public revenues to GDP.

When TOTCHDEF is used, given variables are replaced by dTOTGDP, dTOTUNR and TOTINFL. The coefficients on DGDP, DUNR and INFL are the coefficients on these variables. 
Table 3 - Probit coefficients (full sample), with additional controls

\begin{tabular}{|c|c|c|c|c|c|}
\hline VARIABLES & $\begin{array}{c}\text { (1) } \\
\text { IDEOCH }\end{array}$ & $\begin{array}{c}\text { (2) } \\
\text { IDEOCH }\end{array}$ & $\begin{array}{c}\text { (3) } \\
\text { IDEOCH }\end{array}$ & $\begin{array}{c}\text { (4) } \\
\text { IDEOCH }\end{array}$ & $\begin{array}{c}\text { (5) } \\
\text { IDEOCH }\end{array}$ \\
\hline CHDEF $^{1}$ & $\begin{array}{l}-0.0663 \\
(0.053)\end{array}$ & & & & \\
\hline COCHDEF $^{2}$ & & $\begin{array}{l}0.0125 \\
(0.058)\end{array}$ & & & \\
\hline TOTCHDEF $^{3}$ & & & $\begin{array}{l}-0.0210 \\
(0.070)\end{array}$ & & \\
\hline CHEXP $^{4}$ & & & & $\begin{array}{l}-0.0325 \\
(0.068)\end{array}$ & \\
\hline CHREV $^{5}$ & & & & & $\begin{array}{l}0.0619 \\
(0.062)\end{array}$ \\
\hline DGDP & $\begin{array}{l}-0.0857 \\
(0.060)\end{array}$ & $\begin{array}{l}-0.0688 \\
(0.062)\end{array}$ & $\begin{array}{c}-0.1545^{* *} \\
(0.061)\end{array}$ & $\begin{array}{r}-0.0820 \\
(0.064)\end{array}$ & $\begin{array}{l}-0.0603 \\
(0.059)\end{array}$ \\
\hline DUNR & $\begin{array}{l}0.0010 \\
(0.005)\end{array}$ & $\begin{array}{l}-0.0026 \\
(0.006)\end{array}$ & $\begin{array}{l}-0.0075 \\
(0.006)\end{array}$ & $\begin{array}{l}-0.0007 \\
(0.005)\end{array}$ & $\begin{array}{l}0.0000 \\
(0.005)\end{array}$ \\
\hline INFL & $\begin{array}{c}0.0308^{*} \\
(0.017)\end{array}$ & $\begin{array}{c}0.0425^{* *} \\
(0.017)\end{array}$ & $\begin{array}{c}0.0302^{*} \\
(0.017)\end{array}$ & $\begin{array}{c}0.0344 * * \\
(0.017)\end{array}$ & $\begin{array}{c}0.0332 * * \\
(0.017)\end{array}$ \\
\hline DURAT & $\begin{array}{c}0.2241 * * * \\
(0.050)\end{array}$ & $\begin{array}{c}0.2259 * * * \\
(0.052)\end{array}$ & $\begin{array}{c}0.2236^{* * *} \\
(0.051)\end{array}$ & $\begin{array}{c}0.2221 * * * \\
(0.050)\end{array}$ & $\begin{array}{c}0.2231 * * * \\
(0.050)\end{array}$ \\
\hline COAL & $\begin{array}{l}0.0688 \\
(0.152)\end{array}$ & $\begin{array}{l}0.0666 \\
(0.156)\end{array}$ & $\begin{array}{l}0.0648 \\
(0.154)\end{array}$ & $\begin{array}{l}0.0787 \\
(0.152)\end{array}$ & $\begin{array}{l}0.0789 \\
(0.152)\end{array}$ \\
\hline MAJ & $\begin{array}{l}0.0001 \\
(0.179)\end{array}$ & $\begin{array}{l}-0.0282 \\
(0.183)\end{array}$ & $\begin{array}{l}-0.0428 \\
(0.180)\end{array}$ & $\begin{array}{l}-0.0125 \\
(0.179)\end{array}$ & $\begin{array}{l}0.0017 \\
(0.179)\end{array}$ \\
\hline DGDPg7 & $\begin{array}{l}0.0520 \\
(0.055)\end{array}$ & $\begin{array}{l}0.0369 \\
(0.058)\end{array}$ & $\begin{array}{l}0.0640 \\
(0.049)\end{array}$ & $\begin{array}{l}0.0439 \\
(0.055)\end{array}$ & $\begin{array}{l}0.0420 \\
(0.054)\end{array}$ \\
\hline UNRg7 & $\begin{array}{l}0.0128 \\
(0.022)\end{array}$ & $\begin{array}{l}0.0199 \\
(0.023)\end{array}$ & $\begin{array}{l}0.0131 \\
(0.022)\end{array}$ & $\begin{array}{l}0.0144 \\
(0.022)\end{array}$ & $\begin{array}{l}0.0151 \\
(0.022)\end{array}$ \\
\hline INFLg7 & $\begin{array}{l}-0.0056 \\
(0.031)\end{array}$ & $\begin{array}{l}-0.0141 \\
(0.032)\end{array}$ & $\begin{array}{l}0.0107 \\
(0.032)\end{array}$ & $\begin{array}{l}-0.0052 \\
(0.032)\end{array}$ & $\begin{array}{l}-0.0138 \\
(0.031)\end{array}$ \\
\hline Constant & $\begin{array}{c}-1.6840 * * * \\
(0.260)\end{array}$ & $\begin{array}{c}-1.7501^{* * *} \\
(0.271)\end{array}$ & $\begin{array}{c}-1.5306^{* * *} \\
(0.266)\end{array}$ & $\begin{array}{c}-1.7003^{* * *} \\
(0.265)\end{array}$ & $\begin{array}{c}-1.7466^{* * *} \\
(0.257)\end{array}$ \\
\hline $\begin{array}{l}\text { Log-likelihood } \\
\text { Observations }\end{array}$ & 613 & 591 & 613 & 614 & 613 \\
\hline
\end{tabular}

Source: see data Appendix at the end of the paper.

Standard errors in parentheses: $* * * p<0.01, * * p<0.05, * p<0.1$.

1. Change in public deficit: percentage point change in the ratio of public deficit to GDP.

2. Change in the primary deficit (CHDEF), corrected for the cycle.

3. Average change in deficit during tenure: average percentage point change in the deficit over the years that the current cabinet has been in power, up to the current year.

4. Change in public expenditures: percentage point change in the ratio of primary expenditures to GDP.

5. Change in public revenues: percentage point change in the ratio of public revenues to GDP.

When TOTCHDEF is used, given variables are replaced by dTOTGDP, dTOTUNR and TOTINFL. The coefficients on DGDP, DUNR and INFL are the coefficients on these variables 
Table 4 - Probit coefficients (using only observations with CHDEF $<0$ )

\begin{tabular}{|c|c|c|c|c|c|}
\hline VARIABLES & $\begin{array}{c}\text { (1) } \\
\text { IDEOCH }\end{array}$ & $\begin{array}{c}\text { (2) } \\
\text { IDEOCH }\end{array}$ & $\begin{array}{c}\text { (3) } \\
\text { IDEOCH }\end{array}$ & $\begin{array}{c}\text { (4) } \\
\text { IDEOCH }\end{array}$ & $\begin{array}{c}\text { (5) } \\
\text { IDEOCH }\end{array}$ \\
\hline CHDEF $^{1}$ & $\begin{array}{l}-0.1454 \\
(0.108)\end{array}$ & & & & \\
\hline COCHDEF $^{2}$ & & $\begin{array}{l}-0.0570 \\
(0.105)\end{array}$ & & & \\
\hline TOTCHDEF $^{3}$ & & & $\begin{array}{l}0.0281 \\
(0.130)\end{array}$ & & \\
\hline CHEXP $^{4}$ & & & & $\begin{array}{l}0.0608 \\
(0.101)\end{array}$ & \\
\hline CHREV $^{5}$ & & & & & $\begin{array}{l}0.2104^{*} \\
(0.109)\end{array}$ \\
\hline DGDP & $\begin{array}{l}-0.0249 \\
(0.060)\end{array}$ & $\begin{array}{l}-0.0515 \\
(0.066)\end{array}$ & $\begin{array}{l}-0.0701 \\
(0.068)\end{array}$ & $\begin{array}{l}-0.0077 \\
(0.063)\end{array}$ & $\begin{array}{l}0.0166 \\
(0.063)\end{array}$ \\
\hline DUNR & $\begin{array}{l}0.0098 \\
(0.009)\end{array}$ & $\begin{array}{l}-0.0035 \\
(0.011)\end{array}$ & $\begin{array}{l}0.0070 \\
(0.009)\end{array}$ & $\begin{array}{l}0.0078 \\
(0.009)\end{array}$ & $\begin{array}{l}0.0061 \\
(0.009)\end{array}$ \\
\hline INFL & $\begin{array}{l}0.0232 \\
(0.019)\end{array}$ & $\begin{array}{l}0.0331^{*} \\
(0.020)\end{array}$ & $\begin{array}{l}0.0273 \\
(0.019)\end{array}$ & $\begin{array}{l}0.0295 \\
(0.018)\end{array}$ & $\begin{array}{l}0.0191 \\
(0.019)\end{array}$ \\
\hline DURAT & $\begin{array}{c}0.1666^{* *} \\
(0.072)\end{array}$ & $\begin{array}{c}0.1550^{* *} \\
(0.077)\end{array}$ & $\begin{array}{l}0.1182 \\
(0.079)\end{array}$ & $\begin{array}{c}0.1624 * * \\
(0.072)\end{array}$ & $\begin{array}{c}0.1691^{* *} \\
(0.073)\end{array}$ \\
\hline COAL & $\begin{array}{l}0.1158 \\
(0.214)\end{array}$ & $\begin{array}{l}0.0903 \\
(0.217)\end{array}$ & $\begin{array}{l}0.1036 \\
(0.216)\end{array}$ & $\begin{array}{l}0.1374 \\
(0.213)\end{array}$ & $\begin{array}{l}0.1236 \\
(0.214)\end{array}$ \\
\hline MAJ & $\begin{array}{l}-0.0443 \\
(0.268)\end{array}$ & $\begin{array}{l}-0.0557 \\
(0.270)\end{array}$ & $\begin{array}{l}-0.0944 \\
(0.268)\end{array}$ & $\begin{array}{l}-0.0554 \\
(0.266)\end{array}$ & $\begin{array}{c}-0.0003 \\
(0.267)\end{array}$ \\
\hline Constant & $\begin{array}{c}-1.8521 * * * \\
(0.351)\end{array}$ & $\begin{array}{c}-1.6941^{* * *} \\
(0.389)\end{array}$ & $\begin{array}{c}-1.4695^{* * *} \\
(0.378)\end{array}$ & $\begin{array}{c}-1.7634 * * * \\
(0.341)\end{array}$ & $\begin{array}{c}-1.9791^{* * *} \\
(0.364)\end{array}$ \\
\hline $\begin{array}{l}\text { Log-likelihood } \\
\text { Observations }\end{array}$ & 325 & 316 & 325 & 325 & 325 \\
\hline
\end{tabular}

Source: see data Appendix at the end of the paper.

Standard errors in parentheses: ${ }^{* * *} p<0.01,{ }^{* *} p<0.05,{ }^{*} p<0.1$.

1. Change in public deficit: percentage point change in the ratio of public deficit to GDP.

2. Change in the primary deficit (CHDEF), corrected for the cycle.

3. Average change in deficit during tenure: average percentage point change in the deficit over the years that the current cabinet has been in power, up to the current year.

4. Change in public expenditures: percentage point change in the ratio of primary expenditures to GDP.

5. Change in public revenues: percentage point change in the ratio of public revenues to GDP.

When TOTCHDEF is used, given variables are replaced by dTOTGDP, dTOTUNR and TOTINFL. The coefficients on DGDP, DUNR and INFL are the coefficients on these variables. 
Table 5 - Probit coefficients (full sample, non-cyclically adjusted variables)

\begin{tabular}{|c|c|c|c|c|}
\hline VARIABLES & $\begin{array}{c}\text { (1) } \\
\text { IDEOCH }\end{array}$ & $\begin{array}{c}\text { (2) } \\
\text { IDEOCH }\end{array}$ & $\begin{array}{c}\text { (3) } \\
\text { IDEOCH }\end{array}$ & $\begin{array}{c}\text { (4) } \\
\text { IDEOCH }\end{array}$ \\
\hline CHDEF $^{1}$ & $\begin{array}{l}-0.0907 \\
(0.057)\end{array}$ & $\begin{array}{l}-0.0444 \\
(0.060)\end{array}$ & $\begin{array}{l}-0.0812 \\
(0.056)\end{array}$ & $\begin{array}{l}-0.0697 \\
(0.059)\end{array}$ \\
\hline DGDP & $\begin{array}{l}-0.0450 \\
(0.042)\end{array}$ & $\begin{array}{l}-0.0438 \\
(0.042)\end{array}$ & $\begin{array}{r}-0.0463 \\
(0.042)\end{array}$ & $\begin{array}{l}-0.0478 \\
(0.042)\end{array}$ \\
\hline DUNR & $\begin{array}{l}0.0016 \\
(0.005)\end{array}$ & $\begin{array}{l}0.0007 \\
(0.005)\end{array}$ & $\begin{array}{l}0.0014 \\
(0.005)\end{array}$ & $\begin{array}{l}0.0010 \\
(0.005)\end{array}$ \\
\hline INFL & $\begin{array}{c}0.0251^{*} \\
(0.013)\end{array}$ & $\begin{array}{c}0.0255^{*} \\
(0.013)\end{array}$ & $\begin{array}{c}0.0252^{*} \\
(0.013)\end{array}$ & $\begin{array}{c}0.0266 * * \\
(0.013)\end{array}$ \\
\hline DURAT & $\begin{array}{c}0.2256^{* * *} \\
(0.050)\end{array}$ & $\begin{array}{c}0.2277^{* * *} \\
(0.050)\end{array}$ & $\begin{array}{c}0.2254^{* * *} \\
(0.050)\end{array}$ & $\begin{array}{c}0.2270^{* * *} \\
(0.050)\end{array}$ \\
\hline COAL & $\begin{array}{l}0.0530 \\
(0.151)\end{array}$ & $\begin{array}{l}0.0479 \\
(0.151)\end{array}$ & $\begin{array}{l}0.0532 \\
(0.150)\end{array}$ & $\begin{array}{l}0.0557 \\
(0.150)\end{array}$ \\
\hline MAJ & $\begin{array}{l}-0.0041 \\
(0.178)\end{array}$ & $\begin{array}{l}0.0033 \\
(0.178)\end{array}$ & $\begin{array}{l}0.0002 \\
(0.178)\end{array}$ & $\begin{array}{l}0.0035 \\
(0.178)\end{array}$ \\
\hline PEXP $^{2}$ & $\begin{array}{l}-0.4227 \\
(0.340)\end{array}$ & & & \\
\hline PTAX $^{3}$ & & $\begin{array}{l}0.1798 \\
(0.292)\end{array}$ & & \\
\hline PTRF $^{4}$ & & & $\begin{array}{l}-0.3040 \\
(0.347)\end{array}$ & \\
\hline PCGW $^{5}$ & & & & $\begin{array}{l}-0.0753 \\
(0.297)\end{array}$ \\
\hline Constant & $\begin{array}{c}-1.7427^{* * *} \\
(0.232)\end{array}$ & $\begin{array}{c}-1.7839 * * * \\
(0.231)\end{array}$ & $\begin{array}{c}-1.7468^{* * *} \\
(0.232)\end{array}$ & $\begin{array}{c}-1.7655^{* * *} \\
(0.231)\end{array}$ \\
\hline Log-likelihood & & & & \\
\hline Observations & 613 & 613 & 613 & 613 \\
\hline
\end{tabular}

Source: see data Appendix at the end of the paper.

Standard errors in parentheses: $* * * p<0.01, * * p<0.05, * p<0.1$

1. Change in public deficit: percentage point change in the ratio of public deficit to GDP.

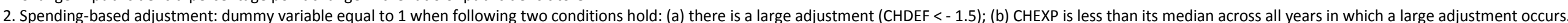

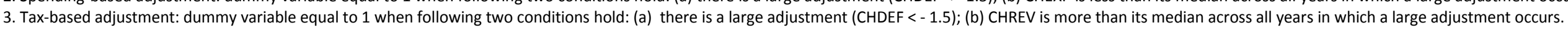

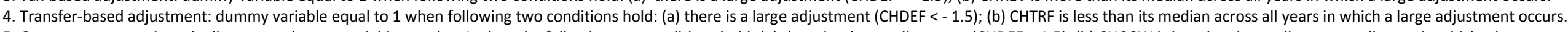

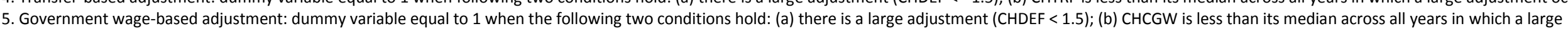

adjustment occurs. 
Table 6 (same variables as table 3) - Logit fixed effects model coefficients (full sample)

\begin{tabular}{|c|c|c|c|c|c|}
\hline VARIABLES & $\begin{array}{c}\text { (1) } \\
\text { IDEOCH }\end{array}$ & $\begin{array}{c}\text { (2) } \\
\text { IDEOCH }\end{array}$ & $\begin{array}{c}\text { (3) } \\
\text { IDEOCH }\end{array}$ & $\begin{array}{c}\text { (4) } \\
\text { IDEOCH }\end{array}$ & $\begin{array}{c}\text { (5) } \\
\text { IDEOCH }\end{array}$ \\
\hline CHDEF $^{1}$ & $\begin{array}{l}-0.1260 \\
(0.100)\end{array}$ & & & & \\
\hline $\mathrm{COCHDEF}^{2}$ & & $\begin{array}{l}-0.0084 \\
(0.109)\end{array}$ & & & \\
\hline TOTCHDEF $^{3}$ & & & $\begin{array}{c}-0.1304 \\
(0.135)\end{array}$ & & \\
\hline CHEXP $^{4}$ & & & & $\begin{array}{l}-0.0997 \\
(0.137)\end{array}$ & \\
\hline CHREV $^{5}$ & & & & & $\begin{array}{l}0.1047 \\
(0.119)\end{array}$ \\
\hline DGDP & $\begin{array}{c}-0.1638 \\
(0.114)\end{array}$ & $\begin{array}{l}-0.1224 \\
(0.116)\end{array}$ & $\begin{array}{c}-0.3396 * * * \\
(0.125)\end{array}$ & $\begin{array}{c}-0.1728 \\
(0.124)\end{array}$ & $\begin{array}{l}-0.1159 \\
(0.112)\end{array}$ \\
\hline DUNR & $\begin{array}{l}0.0034 \\
(0.010)\end{array}$ & $\begin{array}{l}-0.0022 \\
(0.010)\end{array}$ & $\begin{array}{r}-0.0095 \\
(0.012)\end{array}$ & $\begin{array}{l}-0.0004 \\
(0.009)\end{array}$ & $\begin{array}{l}0.0016 \\
(0.010)\end{array}$ \\
\hline INFL & $\begin{array}{l}0.0113 \\
(0.047)\end{array}$ & $\begin{array}{l}0.0407 \\
(0.046)\end{array}$ & $\begin{array}{r}-0.0034 \\
(0.048)\end{array}$ & $\begin{array}{l}0.0168 \\
(0.048)\end{array}$ & $\begin{array}{l}0.0284 \\
(0.045)\end{array}$ \\
\hline COAL & $\begin{array}{l}0.0497 \\
(0.406)\end{array}$ & $\begin{array}{l}0.1209 \\
(0.415)\end{array}$ & $\begin{array}{l}-0.0311 \\
(0.410)\end{array}$ & $\begin{array}{l}0.0320 \\
(0.406)\end{array}$ & $\begin{array}{l}0.0269 \\
(0.407)\end{array}$ \\
\hline MAJ & $\begin{array}{l}-0.3609 \\
(0.433)\end{array}$ & $\begin{array}{l}-0.3537 \\
(0.435)\end{array}$ & $\begin{array}{l}-0.4716 \\
(0.435)\end{array}$ & $\begin{array}{l}-0.3877 \\
(0.434)\end{array}$ & $\begin{array}{l}-0.3539 \\
(0.434)\end{array}$ \\
\hline DGDPg7 & $\begin{array}{l}0.0716 \\
(0.104)\end{array}$ & $\begin{array}{l}0.0681 \\
(0.110)\end{array}$ & $\begin{array}{l}0.0909 \\
(0.091)\end{array}$ & $\begin{array}{l}0.0589 \\
(0.103)\end{array}$ & $\begin{array}{l}0.0630 \\
(0.103)\end{array}$ \\
\hline UNRg7 & $\begin{array}{l}0.0252 \\
(0.059)\end{array}$ & $\begin{array}{l}0.0784 \\
(0.063)\end{array}$ & $\begin{array}{l}0.0067 \\
(0.059)\end{array}$ & $\begin{array}{l}0.0237 \\
(0.061)\end{array}$ & $\begin{array}{l}0.0435 \\
(0.058)\end{array}$ \\
\hline INFLg7 & $\begin{array}{l}0.0484 \\
(0.072)\end{array}$ & $\begin{array}{l}0.0368 \\
(0.074)\end{array}$ & $\begin{array}{l}0.0917 \\
(0.076)\end{array}$ & $\begin{array}{l}0.0535 \\
(0.077)\end{array}$ & $\begin{array}{l}0.0212 \\
(0.072)\end{array}$ \\
\hline Log-likelihood & & & & & \\
\hline Observations & 580 & 558 & 580 & 581 & 580 \\
\hline Number of countries & 18 & 18 & 18 & 18 & 18 \\
\hline
\end{tabular}

Source: see data Appendix at the end of the paper.

Standard errors in parentheses: ${ }^{* * *} p<0.01, * * p<0.05, * p<0.1$.

1. Change in public deficit: percentage point change in the ratio of public deficit to GDP.

2. Change in the primary deficit (CHDEF), corrected for the cycle.

3. Average change in deficit during tenure: average percentage point change in the deficit over the years that the current cabinet has been in power, up to the current year.

4. Change in public expenditures: percentage point change in the ratio of primary expenditures to GDP.

5. Change in public revenues: percentage point change in the ratio of public revenues to GDP.

When TOTCHDEF is used, given variables are replaced by dTOTGDP, dTOTUNR and TOTINFL. The coefficients on DGDP, DUNR and INFL are the coefficients on these variables. 
Table 7 - Fiscal adjustments using different definitions of executive

\begin{tabular}{|c|c|c|c|c|c|c|}
\hline & $\begin{array}{l}N^{\circ} \text { OF OBSERVATIONS } \\
(1975-2008) \\
\text { (a) }\end{array}$ & $\begin{array}{c}\text { Nº OF FISCAL ADJUSTMENTS }_{(1975-2008)} \\
\text { (b) } \\
\end{array}$ & $\begin{array}{l}\mathrm{N}^{\circ} \text { OF LARGE FISCAL ADJUSTMENTS } \\
(1975-2008) \\
\text { (c) }\end{array}$ & $\%(b) /(a)$ & $\%(c) /(a)$ & $\begin{array}{c}\text { AVERAGE COCHDEF } \\
(1975-2008)\end{array}$ \\
\hline NO ABSOLUTE MAJORITY & 465 & 229 & 47 & $49.2 \%$ & $10.1 \%$ & -0.00794 \\
\hline ABSOLUTE MAJORITY & 127 & 62 & 13 & $48.8 \%$ & $10.2 \%$ & 0.1465567 \\
\hline SINGLE PARTY & 253 & 130 & 26 & $51.4 \%$ & $10.3 \%$ & 0.0291018 \\
\hline COALITION OF PARTIES & 347 & 164 & 34 & $47.3 \%$ & $9.8 \%$ & 0.0296184 \\
\hline
\end{tabular}

Source: Authors' calculations on OECD Economic Outlook Database no.84 and DPI 2009. 
Figure 4 - Frequency in cabinet changes and fiscal adjustments (Single party/Coalition)

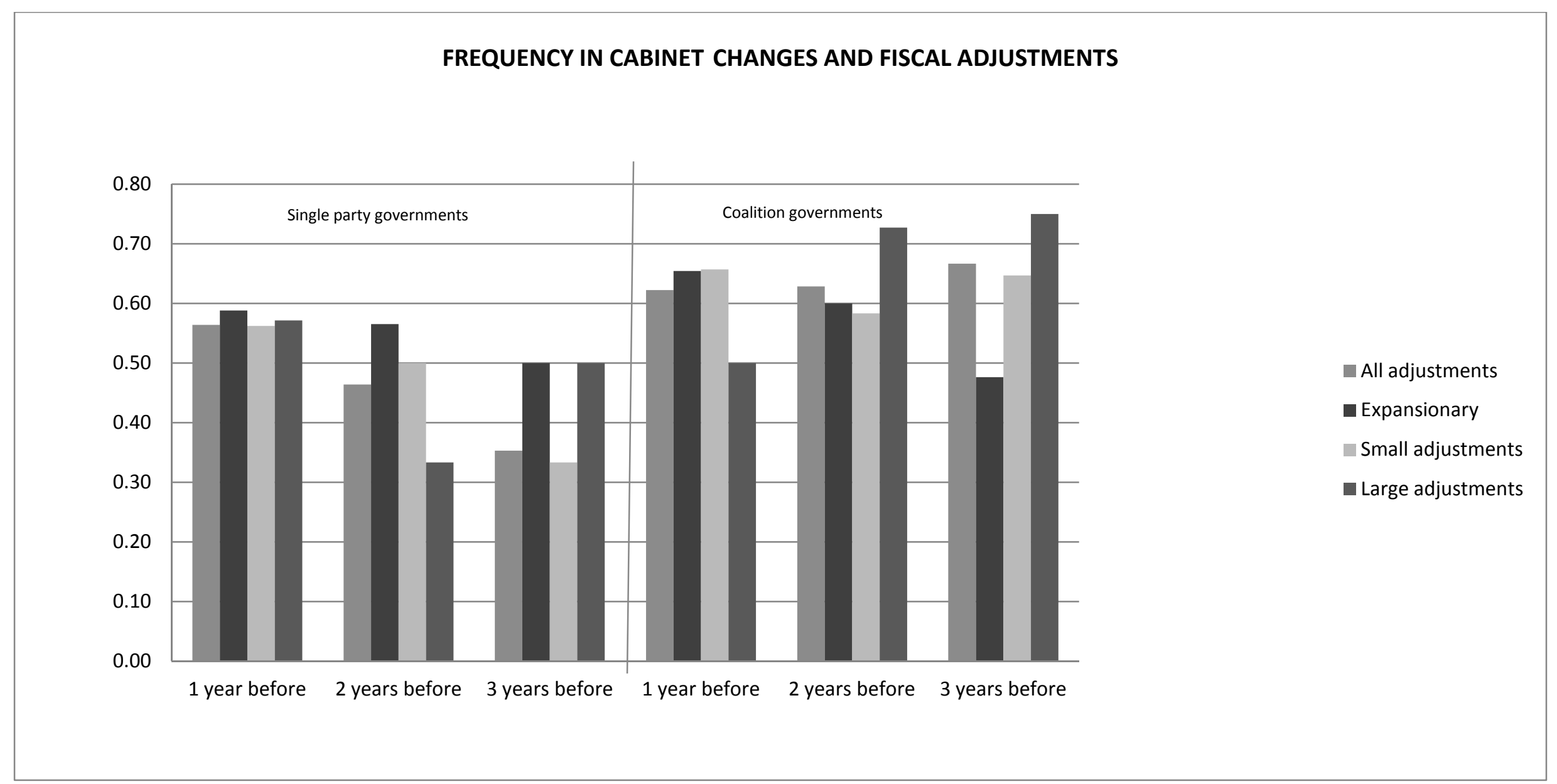

Source: Authors' calculations on OECD Economic Outlook Database no.84 and DPI 2009. 
Figure 5 - Frequency in changes of cabinet ideology and fiscal adjustments (Single party/Coalition)

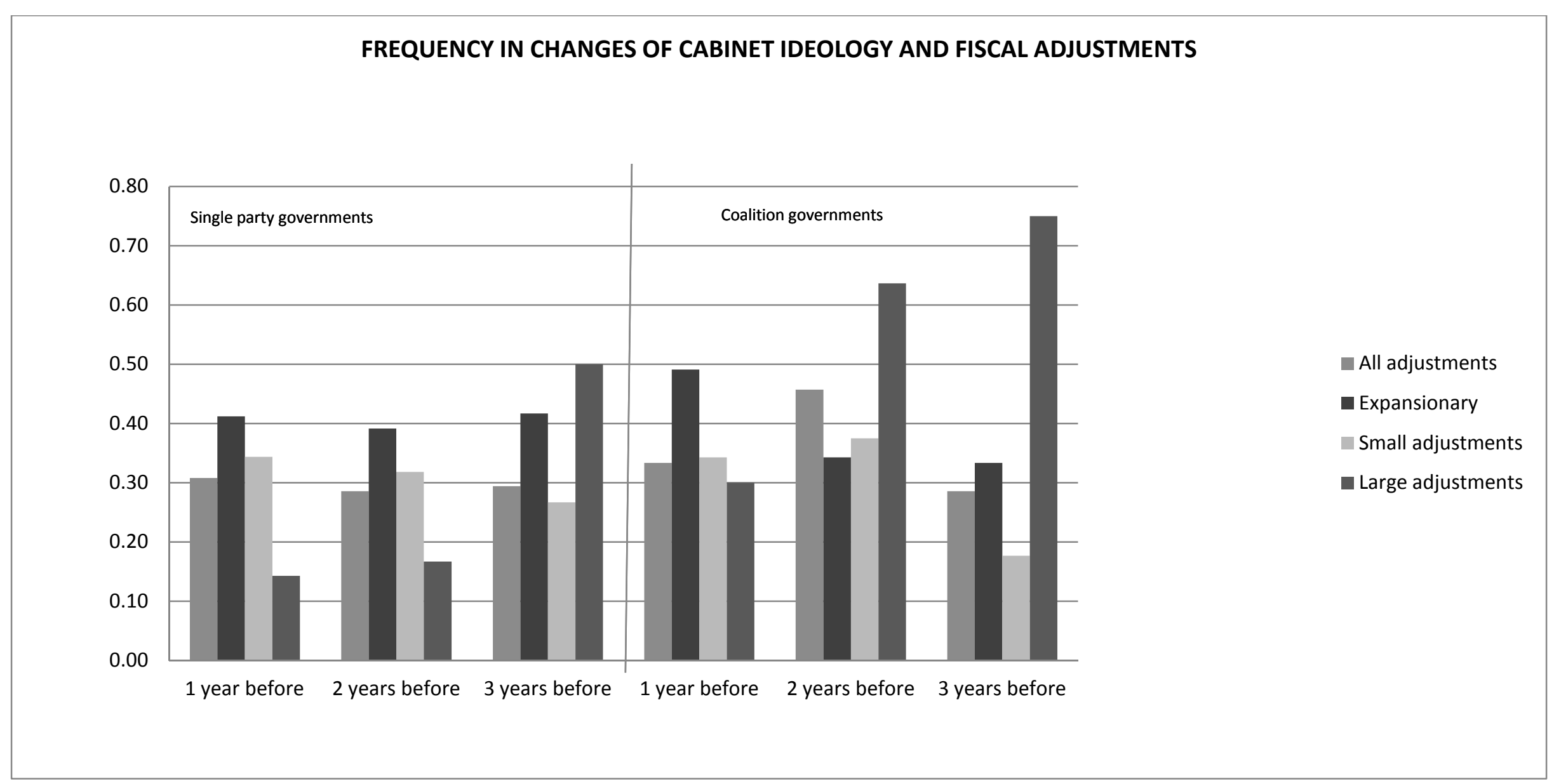

Source: Authors' calculations on OECD Economic Outlook Database no.84 and DPI 2009. 
Figure 6 - Frequency in cabinet changes and fiscal adjustments ( Majority/No Majority)

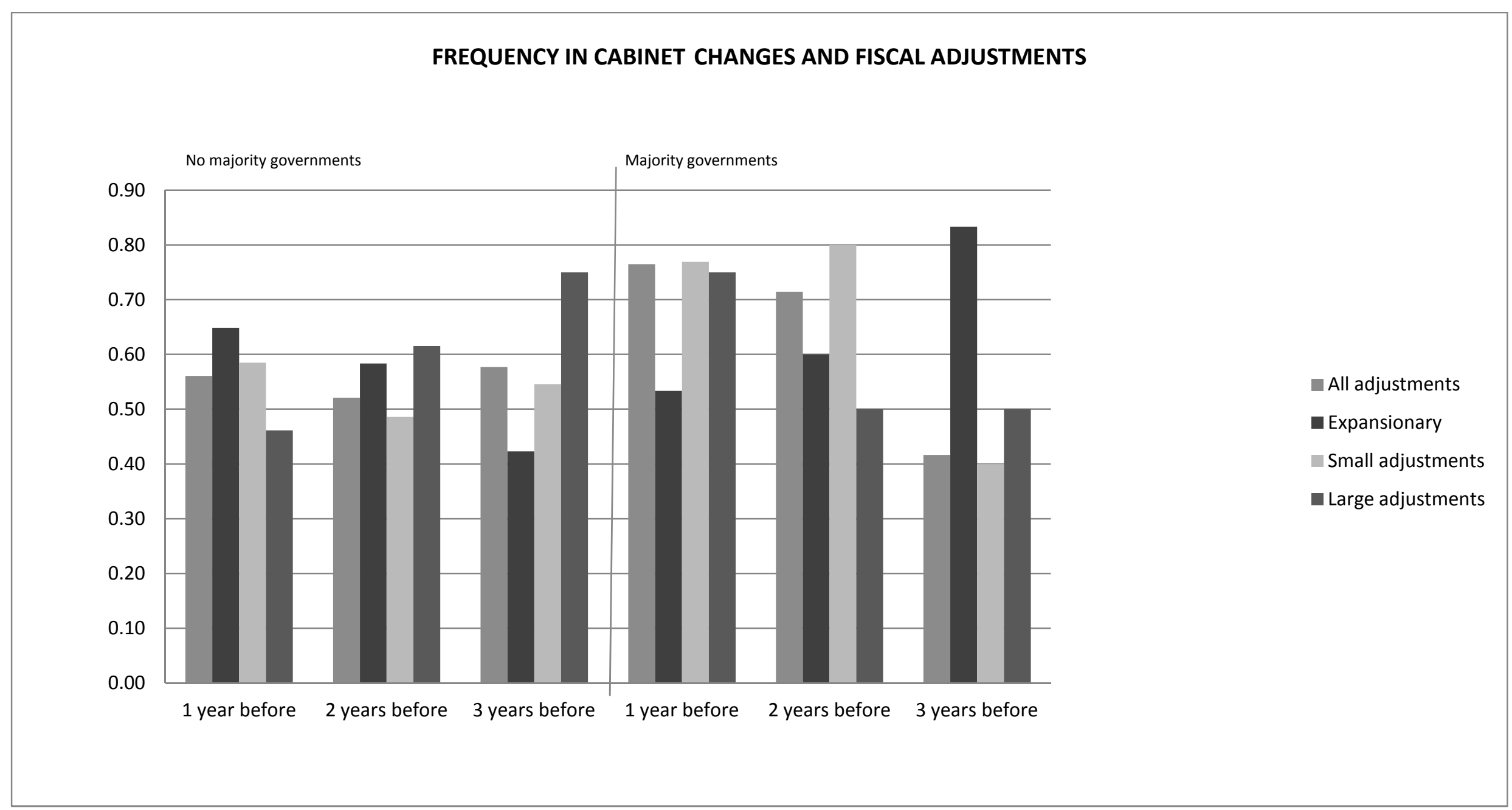

Source: Authors' calculations on OECD Economic Outlook Database no.84 and DPI 2009. 
Figure 7 - Frequency in changes of cabinet ideology and fiscal adjustments ( Majority/No Majority)

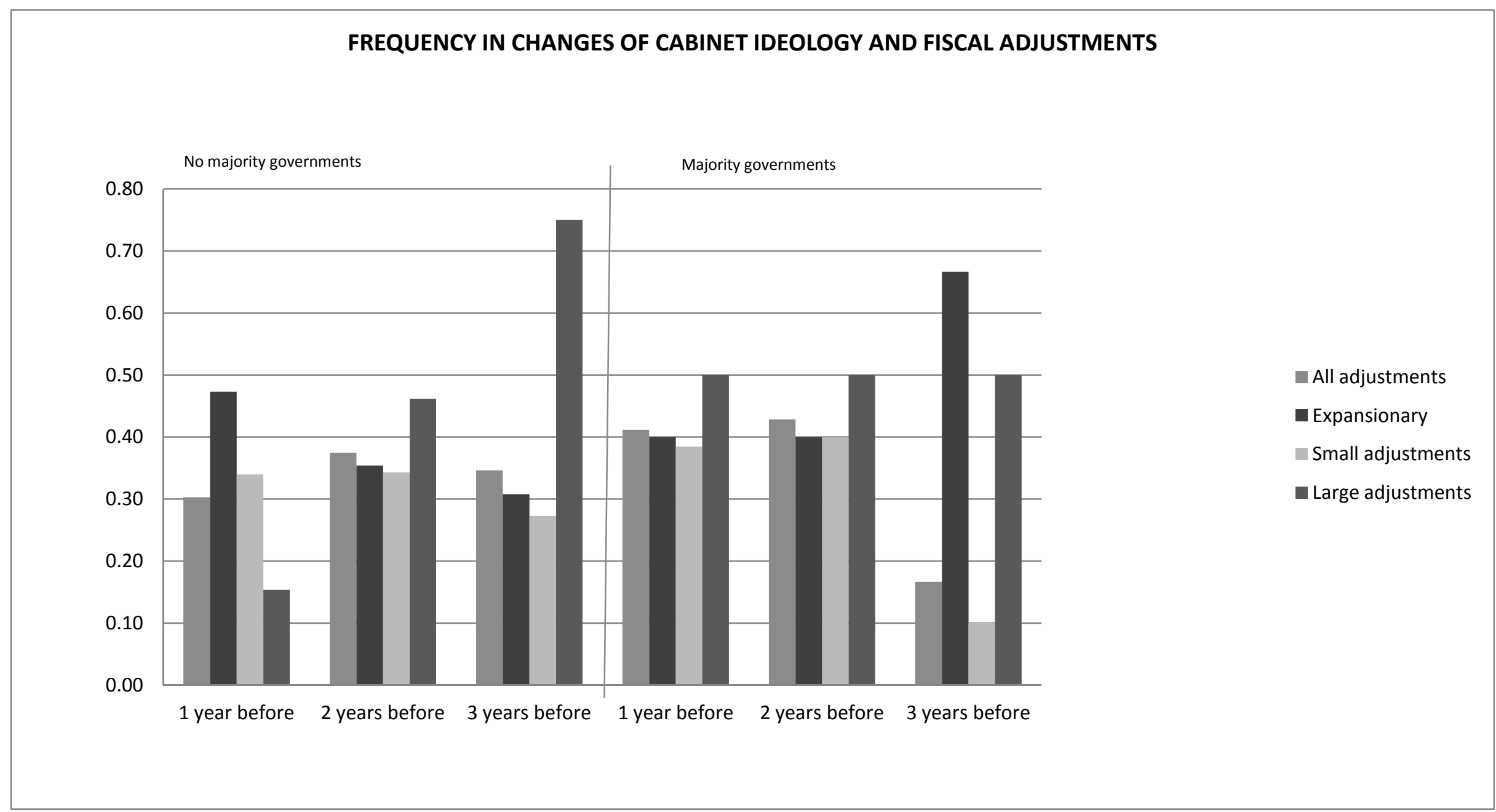

Source: Authors' calculations on OECD Economic Outlook Database no.84 and DPI 2009. 
Table 8 - Probit coefficients (Coalition interaction term)

\begin{tabular}{|c|c|c|c|c|c|c|}
\hline VARIABLES & $\begin{array}{c}\text { (1) } \\
\text { IDEOCH } \\
\end{array}$ & $\begin{array}{c}\text { (2) } \\
\text { IDEOCH } \\
\end{array}$ & $\begin{array}{c}\text { (3) } \\
\text { IDEOCH } \\
\end{array}$ & $\begin{array}{c}\text { (4) } \\
\text { IDEOCH } \\
\end{array}$ & $\begin{array}{c}\text { (5) } \\
\text { IDEOCH } \\
\end{array}$ & $\begin{array}{c}(6) \\
\text { IDEOCH } \\
\end{array}$ \\
\hline CHDEF $^{1}$ & $\begin{array}{l}-0.0627 \\
(0.052)\end{array}$ & $\begin{array}{l}-0.0817 \\
(0.077)\end{array}$ & & & & \\
\hline CHDEF $^{*}$ COAL $^{2}$ & & $\begin{array}{l}0.0311 \\
(0.093)\end{array}$ & & & & \\
\hline COCHDEF $^{3}$ & & & $\begin{array}{l}0.0039 \\
(0.056)\end{array}$ & $\begin{array}{l}-0.0321 \\
(0.083)\end{array}$ & & \\
\hline COCHDEF $^{*}$ COAL $^{4}$ & & & & $\begin{array}{l}0.0652 \\
(0.110)\end{array}$ & & \\
\hline TOTCHDEF $^{5}$ & & & & & $\begin{array}{l}-0.0100 \\
(0.067)\end{array}$ & $\begin{array}{l}-0.0284 \\
(0.094)\end{array}$ \\
\hline TOTCHDEF COAL $^{6}$ & & & & & & $\begin{array}{l}0.0321 \\
(0.116)\end{array}$ \\
\hline DGDP & $\begin{array}{l}-0.0471 \\
(0.042)\end{array}$ & $\begin{array}{r}-0.0470 \\
(0.042)\end{array}$ & $\begin{array}{l}-0.0439 \\
(0.044)\end{array}$ & $\begin{array}{l}-0.0426 \\
(0.044)\end{array}$ & $\begin{array}{c}-0.1039 * * \\
(0.048)\end{array}$ & $\begin{array}{c}-0.1032^{* *} \\
(0.048)\end{array}$ \\
\hline DUNR & $\begin{array}{l}0.0009 \\
(0.005)\end{array}$ & $\begin{array}{l}0.0010 \\
(0.005)\end{array}$ & $\begin{array}{l}-0.0030 \\
(0.005)\end{array}$ & $\begin{array}{l}-0.0028 \\
(0.005)\end{array}$ & $\begin{array}{l}-0.0066 \\
(0.006)\end{array}$ & $\begin{array}{c}-0.0066 \\
(0.006)\end{array}$ \\
\hline INFL & $\begin{array}{c}0.0266^{* *} \\
(0.013)\end{array}$ & $\begin{array}{c}0.0269 * * \\
(0.013)\end{array}$ & $\begin{array}{c}0.0342^{* *} \\
(0.014)\end{array}$ & $\begin{array}{c}0.0347^{* *} \\
(0.014)\end{array}$ & $\begin{array}{c}0.0309 * * \\
(0.013)\end{array}$ & $\begin{array}{c}0.0313^{* *} \\
(0.013)\end{array}$ \\
\hline DURAT & $\begin{array}{c}0.2265^{* * *} \\
(0.050)\end{array}$ & $\begin{array}{c}0.2286^{* * *} \\
(0.050)\end{array}$ & $\begin{array}{c}0.2273^{* * *} \\
(0.052)\end{array}$ & $\begin{array}{c}0.2299 * * * \\
(0.052)\end{array}$ & $\begin{array}{c}0.2295 * * * \\
(0.051)\end{array}$ & $\begin{array}{c}0.2314^{* * *} \\
(0.051)\end{array}$ \\
\hline COAL & $\begin{array}{l}0.0547 \\
(0.150)\end{array}$ & $\begin{array}{l}0.0562 \\
(0.150)\end{array}$ & $\begin{array}{l}0.0493 \\
(0.154)\end{array}$ & $\begin{array}{l}0.0483 \\
(0.154)\end{array}$ & $\begin{array}{l}0.0450 \\
(0.152)\end{array}$ & $\begin{array}{l}0.0450 \\
(0.152)\end{array}$ \\
\hline MAJ & $\begin{array}{l}0.0039 \\
(0.178)\end{array}$ & $\begin{array}{l}0.0059 \\
(0.178)\end{array}$ & $\begin{array}{l}-0.0154 \\
(0.182)\end{array}$ & $\begin{array}{l}-0.0107 \\
(0.182)\end{array}$ & $\begin{array}{l}-0.0467 \\
(0.179)\end{array}$ & $\begin{array}{l}-0.0477 \\
(0.179)\end{array}$ \\
\hline Constant & $\begin{array}{c}-1.7700^{* * *} \\
(0.230)\end{array}$ & $\begin{array}{c}-1.7789 * * * \\
(0.232)\end{array}$ & $\begin{array}{c}-1.8006^{* * *} \\
(0.242)\end{array}$ & $\begin{array}{c}-1.8141^{* * *} \\
(0.244)\end{array}$ & $\begin{array}{c}-1.6166^{* * *} \\
(0.237)\end{array}$ & $\begin{array}{c}-1.6266^{* * *} \\
(0.240)\end{array}$ \\
\hline Log-likelihood & & & & & & \\
\hline Observations & 613 & 613 & 591 & 591 & 613 & 613 \\
\hline
\end{tabular}

Source: see data Appendix at the end of the paper.

Standard errors in parentheses: $* * * p<0.01, * * p<0.05, * p<0.1$.

1. Change in public deficit: percentage point change in the ratio of public deficit to GDP.

2. Interaction variable interacting CHDEF and a dummy variable controlling for coalition governments.

3. Change in the primary deficit (CHDEF), corrected for the cycle.

4. Interaction variable interacting COCHDEF and a dummy variable controlling for coalition governments.

5. Average change in deficit during tenure: average percentage point change in the deficit over the years that the current cabinet has been in power, up to the current year

6. Interaction variable interacting TOTCHDEF and a dummy variable controlling for coalition governments.

When TOTCHDEF is used, given variables are replaced by dTOTGDP, dTOTUNR and TOTINFL. The coefficients on DGDP, DUNR and INFL are the coefficients on these variables. 
Table 9 - Probit coefficients (Majority interaction term)

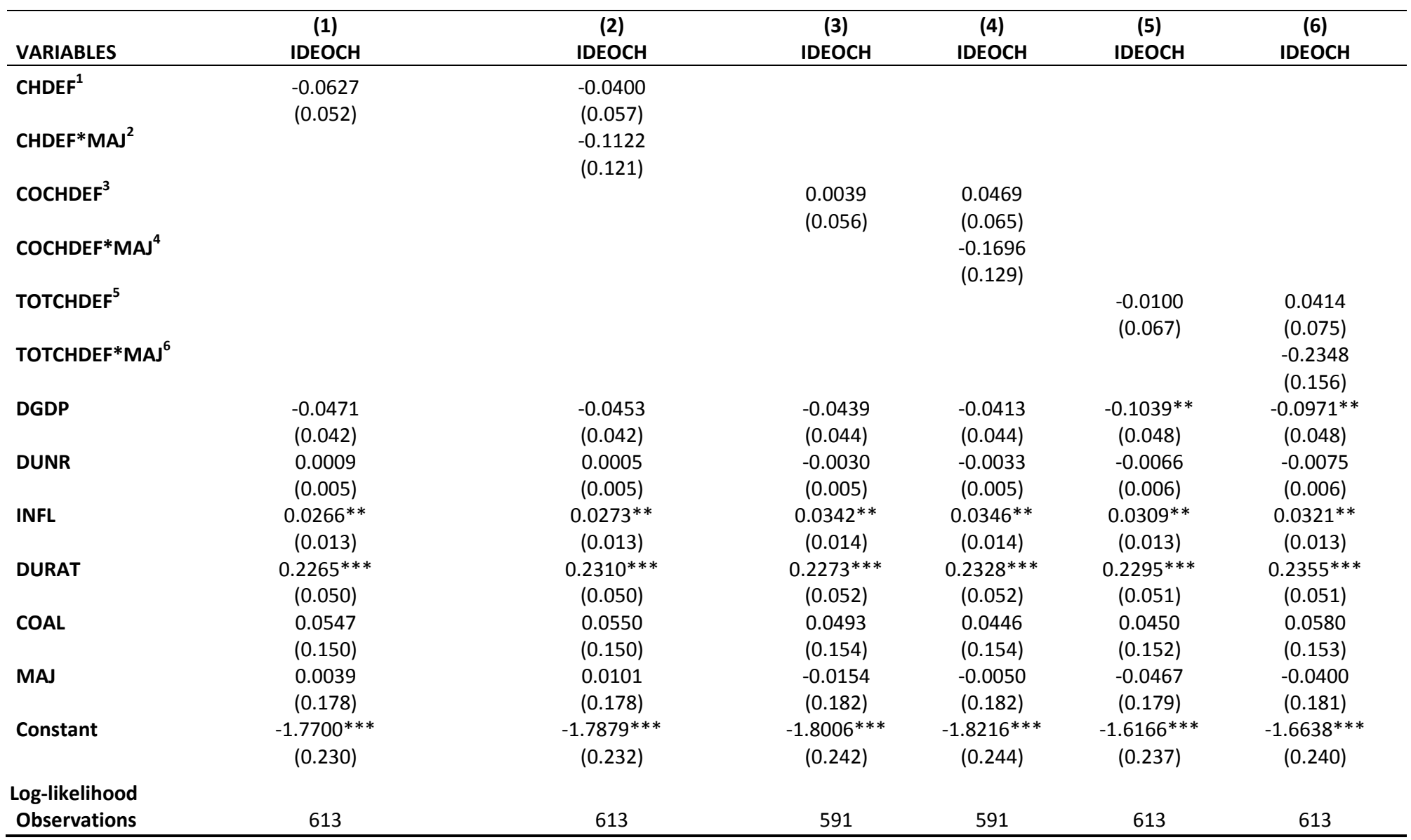

Source: see data Appendix at the end of the paper.

Standard errors in parentheses: $* * * p<0.01, * * p<0.05, * p<0.1$.

1. Change in public deficit: percentage point change in the ratio of public deficit to GDP.

2. Interaction variable interacting CHDEF and a dummy variable controlling for governments with majority support in parliament.

3. Change in the primary deficit (CHDEF), corrected for the cycle.

4. Interaction variable interacting COCHDEF and a dummy variable controlling for governments with majority support in parliament.

5. Average change in deficit during tenure: average percentage point change in the deficit over the years that the current cabinet has been in power, up to the current year.

6. Interaction variable interacting TOTCHDEF and a dummy variable controlling for governments with majority support in parliament.

When TOTCHDEF is used, given variables are replaced by dTOTGDP, dTOTUNR and TOTINFL. The coefficients on DGDP, DUNR and INFL are the coefficients on these variables. 
Table 10: Vote Shares and Seats by Election in Canada 1993-2000

\begin{tabular}{|c|c|c|c|c|c|c|c|c|}
\hline & $\begin{array}{c}199 \\
\begin{array}{c}\text { Percentage } \\
\text { Share of } \\
\text { Votes }\end{array} \\
\end{array}$ & Seats & $\begin{array}{c}199 \\
\begin{array}{c}\text { Percentage } \\
\text { Share of } \\
\text { Votes }\end{array} \\
\end{array}$ & Seats & $\begin{array}{r}2000 \\
\text { Percentage } \\
\text { Share of Votes }\end{array}$ & Seats & $\begin{array}{c}\text { Change in } \\
\text { share 1997- } \\
1993\end{array}$ & $\begin{array}{c}\text { Change in share } \\
2000-1997\end{array}$ \\
\hline Liberal Party of Canada & 41.3 & 177 & 38.5 & 155 & 40.8 & 172 & -2.8 & 2.3 \\
\hline Bloc Québécois & 13.5 & 54 & 10.7 & 44 & 10.7 & 38 & -2.8 & 0 \\
\hline Reform Party of Canada & 18.7 & 52 & 19.4 & 60 & 25.5 & 66 & 0.7 & 6.1 \\
\hline New Democratic Party & 6.9 & 9 & 11 & 21 & 8.5 & 13 & 4.1 & -2.5 \\
\hline $\begin{array}{l}\text { Progressive Conservative } \\
\text { Party of Canada }\end{array}$ & 16 & 2 & 18.8 & 20 & 12.2 & 12 & 2.8 & -6.6 \\
\hline Others & 3.6 & 1 & 1.6 & 1 & 2.3 & 0 & -2 & 0.7 \\
\hline
\end{tabular}

Source: Elections Canada 
Table 11: Vote Shares and Seats by Election in Finland 1995-2003

\begin{tabular}{|c|c|c|c|c|c|c|c|c|}
\hline & $\begin{array}{c}\text { Percentage } \\
\text { Share of } \\
\text { Votes }\end{array}$ & Seats & $\begin{array}{c}19 \\
\text { Percentage } \\
\text { Share of } \\
\text { Votes }\end{array}$ & Seats & $\begin{array}{c}\text { Percentage } \\
\text { Share of } \\
\text { Votes }\end{array}$ & Seats & $\begin{array}{c}\text { Change in share } \\
1999-1995\end{array}$ & $\begin{array}{c}\text { Change in share } \\
\text { 2003-1999 }\end{array}$ \\
\hline $\begin{array}{l}\text { Social Democratic Party of } \\
\text { Finland }\end{array}$ & 28.3 & 63 & 22.9 & 51 & 24.5 & 53 & -5.4 & 1.6 \\
\hline Centre Party & 19.8 & 44 & 22.4 & 48 & 24.7 & 55 & 2.6 & 2.3 \\
\hline National Coalition Party & 17.9 & 39 & 21 & 46 & 18.6 & 40 & 3.1 & -2.4 \\
\hline Left Alliance & 11.2 & 22 & 10.9 & 20 & 9.9 & 19 & -0.3 & -1 \\
\hline Swedish People's Party & 5.1 & 11 & 5.1 & 11 & 4.6 & 8 & 0 & -0.5 \\
\hline Green League & 6.5 & 9 & 7.3 & 11 & 8 & 14 & 0.8 & 0.7 \\
\hline Christian League of Finland & 3 & 7 & 4.2 & 10 & 5.3 & 7 & 1.2 & 1.1 \\
\hline Progressive Finnish Party & 2.8 & 2 & 1 & 0 & - & - & - & - \\
\hline Finnish Rural Party & 1.3 & 1 & - & 0 & - & - & - & - \\
\hline Others & 4.1 & 2 & 5.2 & 3 & 4.4 & 4 & 1.1 & -0.8 \\
\hline
\end{tabular}

Source: Statistics Finland 
Table 12: Vote Shares and Seats by Election in Sweden 1994-2002

\begin{tabular}{|c|c|c|c|c|c|c|c|c|}
\hline & $\begin{array}{l}1994 \\
\text { Percentage } \\
\text { Share of } \\
\text { Votes }\end{array}$ & Seats & $\begin{array}{l}1998 \\
\text { Percentage } \\
\text { Share of } \\
\text { Votes }\end{array}$ & Seats & $\begin{array}{c}20 \\
\text { Percentage } \\
\text { Share of } \\
\text { Votes }\end{array}$ & Seats & $\begin{array}{c}\text { Change in share } \\
1998-1994\end{array}$ & $\begin{array}{c}\text { Change in share } \\
2002-1998\end{array}$ \\
\hline Moderate Party & 22.4 & 80 & 22.9 & 82 & 15.3 & 55 & 0.5 & -7.6 \\
\hline Centre Party & 7.7 & 27 & 5.1 & 18 & 6.2 & 22 & -2.6 & 1.1 \\
\hline Liberal Party & 7.2 & 26 & 4.7 & 17 & 13.4 & 48 & -2.5 & 8.7 \\
\hline Christian Democratic Party & 4.1 & 15 & 11.7 & 42 & 9.1 & 33 & 7.6 & -2.6 \\
\hline Green Party & 5 & 18 & 4.5 & 16 & 4.6 & 17 & -0.5 & 0.1 \\
\hline Social Democratic Party & 45.3 & 161 & 36.4 & 131 & 39.9 & 144 & -8.9 & 3.5 \\
\hline Left Party & 6.2 & 22 & 12 & 43 & 8.4 & 30 & 5.8 & -3.6 \\
\hline Others & 2.3 & - & 2.6 & - & 3.1 & - & 0.3 & 0.5 \\
\hline
\end{tabular}

Source: SCB - Statistics Sweden 
Table 13: Vote Shares and Seats by Election in the UK 1992-1997

\begin{tabular}{|c|c|c|c|c|c|}
\hline & $\begin{array}{c}199 \\
\text { Percentage } \\
\text { Share of } \\
\text { Votes }\end{array}$ & Seats & $\begin{array}{c}199 \\
\text { Percentage } \\
\text { Share of } \\
\text { Votes }\end{array}$ & Seats & $\begin{array}{c}\text { Change in share } \\
1997-1993\end{array}$ \\
\hline Labour & 34.4 & 274 & 43.2 & 418 & 8.8 \\
\hline Conservative & 41.9 & 343 & 30.7 & 165 & -11.2 \\
\hline Liberal Democratic & 17.8 & 18 & 16.8 & 46 & -1 \\
\hline Others & 5.9 & 24 & 9.3 & 30 & 3.4 \\
\hline
\end{tabular}

Source: UK Parliament 